KNOWLEDGE GAPS IN DEMOGRAPHIC, SPATIAL, AND BIOLOGICAL CHARACTERISTICS OF CANADIAN AT-RISK PLANT SPECIES

by

Rebecca J. Parker

BSc Dalhousie University, 2012

A thesis presented to Ryerson University

In fulfillment of the degree of

Master of Applied Science

In Environmental Applied Science and Management

Toronto, Ontario, Canada, 2014

(C) Rebecca J. Parker, 2014 
I hereby declare that I am the sole author of this thesis. This is a true copy of the thesis, including any required final revisions, as accepted by my examiners.

I authorize Ryerson University to lend this thesis to other institutions or individuals for the purpose of scholarly research

I further authorize Ryerson University to reproduce this thesis by photocopying or by other means, in total or in part, at the request of other institutions or individuals for the purpose of scholarly research.

I understand that my thesis may be made electronically available to the public.

\section{PQarker}

Rebecca Judith Marie Parker 


\title{
ABSTRACT \\ KNOWLEDGE GAPS IN DEMOGRAPHIC, SPATIAL, AND BIOLOGICAL CHARACTERISTICS OF CANADIAN AT-RISK PLANT SPECIES
}

\author{
Rebecca Judith Marie Parker for Ryerson University \\ Master of Applied Science \\ Environmental Applied Science and Management, 2014
}

There are gaps in abundance, distribution, and biological information for many at-risk species, likely because of surveying difficulties. I outline these gaps for Canadian plant species and also suggest species-specific traits that hint at which species are difficult to assess in the field, therefore making them more likely to report missing data. A metaanalysis of COSEWIC listed plant species revealed that only 103 (60\%) species had available status reports in 2013. Furthermore, $20 \%$ of those species had at least one missing population. Fifty-eight percent of missing information was attributable to missing abundance estimates, $24 \%$ percent to geographical information, and $18 \%$ to biological information. Finally, a Poisson distribution ANCOVA revealed no significant differences between species reporting uncertain populations and species not reporting such populations, nor in the amount of missing data they reported, with respect to any of the traits identified as potential indicators of surveying difficulty.

Keywords: COSEWIC, SARA, quantitative, ephemerality, demographic stochasticity, isolation, fragmentation, abundance estimates, distribution, at-risk, missing information, status reports, conservation, survey inefficiencies 


\section{ACKNOWLEDGEMENTS}

I'd like to thank firstly Dr. Campbell for her unfailing guidance and advice, many hours editing, and above and beyond academic support, all present and former members of the Campbell lab that advised on analyses and edited this thesis: Zachary Teitel, Agnes Klimowski, and Matthew Woods, the committee and chair for their comments and edits, the friends outside of academia for fresh interpretation, and finally my family for their everlasting love and support in all my ventures. 


\section{TABLE OF CONTENTS}

1. INTRODUCTION

1.1 Species Conservation in Canada 2

1.1.1. Legal Obligations of the Government and Process for 2 Conservation

1.1.2. Data Needed to Conserve Species 4

1.2. Methods Currently Used to Find and Collect Data from Plant Populations 5

1.2.2. Technical Approaches to Data Collection 5

1.2.1. Species Specific Information 6

1.3. The Difficulties in Obtaining Accurate Data for Plant Populations $\quad 7$

1.3.1. Resource Constraints Limit Resolution in the Field 7

1.3.2. Estimating Population Characteristics is Difficult When Data 9 Availability is Limited

1.3.3. There Has Been Limited Review or Application of Best 10 Practices for Plant Survey Techniques

1.4. The Consequences of Unreliable or Missing Conservation data 11

1.5. Species Traits That May Reduce the Reliability of Survey Data 11

1.5.1. Ephemerality 13

1.5.2. Susceptibility to Stochasticity 14

1.5.3. Geographical Isolation $\quad 15$

1.6. Objectives of This Study 16

$\begin{array}{ll}\text { 2. METHODS } & 19\end{array}$

2.1. COSEWIC Status Reports in 2013

2.2. Standardization of Data Collected from COSEWIC Status Reports $\quad 20$

2.3. Data Collection and Analysis by Question 22 
2.3.1. Question 1: Which Population Parameters Are Missing

Information?

2.3.2 Question 2: What Proportion of Species Have At Least One

Population of Uncertain Status/Existence? How Many Populations of

Uncertain Status Do These Species Have On Average?

2.3.3. Question 3: Are Some Species More Likely to Have Missing Information?

2.3.3.1. Are Particular Species More Likely to Report Missing

Data Points in Report Parameters For Some Common Reason?

2.3.3.2. Are Particular Species More Likely to Report Missing 24 Populations For Some Common Reason?

\section{RESULTS}

3.1. Question 1: Which Population Parameters Are Missing Information?

3.1.1. Biological Information

3.1.2. Abundance Information

3.1.3. Distribution Information

3.2. Question 2: What Proportion of Species Have At Least One Population of Species More Likely to Report Missing Populations For Some Common $\underline{\text { Reason? }}$ Information? 
4.1.1.2. Many Status Reports Are Missing Biological 43 Information

4.1.1.1. Many Status Reports Are Missing Single Population 44 Abundance Estimates

4.1.1.2. Many Status Reports Are Missing Distribution 46 Information

4.1.2. Question 2: What Proportion of Species Have At Least One 46 Population of Uncertain Status/Existence? How Many Populations of Uncertain Status Do These Species Have On Average?

4.1.2.1. Many Status Reports Are Missing Presence/Absence 46 Data for At Least One Population

4.1.3. Summary of Missing Information

4.1.4. Question 3: Are Some Species More Likely to Have Missing 50 Information?

4.1.4.1. Are Particular Species More Likely to Report Missing 50 Data Points in Report Parameters For Some Common Reason?

4.1.4.2. Are Particular Species More Likely to Report Missing Populations For Some Common Reason?

4.2. Implications for Managing Species At Risk 


\section{LIST OF TABLES}

Table 1. Summary of parameter values for all 103 available COSEWIC-listed p. 31 plant species in 2013.

Table 2. COSEWIC at-risk plant species ranked by number of missing data 32 points in the 9 parameters examined in this study.

Table 3. Summary of parameter values for both species reporting populations 39 of uncertain status and species not reporting populations of uncertain status

Table 4. Results of ANCOVA testing whether missing data can be predicted by traits related to species ephemerality, susceptibility to demographic stochasticity, and susceptibility to geographical isolation, using Poisson distribution

Table 5. Results of ANCOVA testing whether populations of uncertain status can be predicted by traits related to species ephemerality, susceptibility to demographic stochasticity, and susceptibility to geographical isolation, using Poisson distribution

Appendix Tables

A-1: Raw data by species name and parameter value taken from the technical 66 report or biology section of COSEWIC status reports for at-risk plant species

A-2: COSEWIC-listed plant species in 2013 by scientific name and status report author

A-3: COSEWIC-listed at-risk plant species $(\mathrm{N}=103)$ summarized by 4 traits $\mathrm{I}$ suggest may make them more likely to report missing data $(0=$ no, $1=$ yes $)$, ranked by total number of traits had. 


\section{LIST OF FIGURES}

Figure 1. Summary of ephemerality traits for COSEWIC-listed plant species p. 28 Status Reports

Figure 2. Frequency of COSEWIC status reports for plant species exhibiting 30 missing data points (blank or unknown entries)

Figure 3. Distribution of missing data in COSEWIC-listed plant species status reports by parameter type

Figure 4. Frequency of uncertain populations among COSEWIC-listed plant 38 species status reports with at least one uncertain population

Figure 5. Frequency of the proportion of uncertain populations among

COSEWIC-listed species status reports with at least one uncertain population 


\title{
KNOWLEDGE GAPS IN DEMOGRAPHIC, SPATIAL, AND BIOLOGICAL CHARACTERISTICS OF CANADIAN AT-RISK PLANT SPECIES
}

\author{
REBCCA J. PARKER
}

\section{INTRODUCTION}

The creation of the International Union for the Protection of Nature, later the International Union for the Conservation of Nature (IUCN), was the first attempt at implementing an international species protection program in response to an observed increase in extinctions and anthropogenic environmental harm around the world. The IUCN was responsible for assessing extinction risk and assigning a formal status designation to each species listed under its program. The process by which the IUCN lists species has since been adopted by many nations worldwide for its reproducibility at a regional scale and scientific objectivity. At first the process was difficult to implement because, traditionally, species protection made heavy use of subjective and widely varying ecological observations. Later though, partly based on Mace and Lande (1991) and Mace (1992), a new system was implemented by which the probability of extinction for any given species was determined by the objective assessment of ecological processes at the population level, later definitively described by quantitative variables (Sleep and Trout, 2013). These include data describing total and regional abundance values, abundance over time, and population sizes and distributions. These criteria are now the formally accepted standard for species assessments in all nations with some kind of endangered species act, including Canada. 


\subsection{Species Conservation in Canada}

\subsubsection{Legal Obligations of the Government and Process for Conservation}

When it was created in 2002 in the wake of widespread adoption of the IUCN criteria for species protection, the Canadian Species at Risk Act (SARA) required the federal government to firstly, identify species in danger of significant population reduction or harm in Canada and secondly, define recovery strategies and provide conservation action guidance for those listed species (Justice Laws, 2002). It simultaneously ratified the Committee on the Status of Endangered Wildlife in Canada (COSEWIC) and charged it to identify species at-risk, develop status assessments, and create recovery plans. According to C.29 - 15 of SARA, COSEWIC must continually identify species for protection and classify them as extinct, extirpated, endangered, threatened, or special concern (Justice Laws, 2002). They must then rank species by conservation priority according to which are more likely to become extinct and identify the current state of each species as well as existing and potential threats to that species in the form of a status report (Justice Laws, 2002). Recovery strategies and action plans then follow based on the information in the status reports. Extirpated, endangered, and threatened species must have recovery strategies, which outline the technical and biological aspects of recovery if recovery is deemed possible. New status assessments must therefore be conducted for listed species every ten years unless there is reason to do so earlier to ensure there is up-to-date and relevant information available to inform recovery strategies (C. $29-24)$. 
The criteria by which status is assessed have largely been adapted from the IUCN quantitative criteria for species assessment and include information on population decline, abundance, and geographical range (Mooers et al., 2007). These must be reviewed internally and best practices recommended to the Minister on a regular basis (Justice Laws, 2002). The Act specifically states a requirement in all functions for the best knowledge available, including scientific, community, and aboriginal knowledge, to be used in every report for listed species (C.29 - 15, 2, Justice Laws, 2002). Therefore, recovery strategies must determine whether the recovery of a species is technically and biologically feasible, as well as create action plans, using the most up-to-date status information about that species, from both government and academic scientific sources. This includes a description of the species itself, both in biological and known spatial terms, identification of the species' critical habitat, and identification of the threats to the species. A recommendation section must be included that comments on goal setting for abundance and distribution objectives (Justice Laws, 2002).

Most provinces and territories have their own acts for managing species at risk as well, typically based on the practices of COSEWIC. Ontario for example created the Committee on the Status of Species at Risk in Ontario (COSSARO) with its 2007 Endangered Species Act. Like COSEWIC, COSSARO is responsible for maintaining and prioritizing species lists $(4,1$, Ontario, 2007) and preparing recovery strategies for those species $(11,2$, Ontario, 2007) based on the best available status information (1, Ontario, 2007). While jurisdiction of non-federal lands technically belongs to the concerned province or territory, the federal government can intervene when particular species 
appear inadequately protected. Therefore, the federal government, in a sense, is responsible for the listing and management of all Canadian species at-risk.

\subsubsection{Data Needed to Conserve Species}

While the Canadian Species at Risk Act does not specifically state data parameters that should be collected for listed species outside of general counts and distribution measures, most recovery strategies directly cite a need for detailed and quantitative population abundance and distribution estimates. This is because extinction risk is assessed via population viability assessment, which compares information on population size (both in numbers and geographical size), instantaneous or long-term population growth rates, recruitment rates, survival rates, and threats to survival, whether natural or anthropogenic (Sleep and Trout, 2013). More broadly, many researchers stress the importance of having quantitative data to properly assess the status of plant species, such as abundance, available for these purposes as well as the reporting of error in estimates (Haines et al., 2013; Schemske et al. 1994; Boersma et al. 2001; Lodge et al., 2006). Qualitative data, such as whether a range is thought to be expanding or receding, for example, related in terms of geographical or taxonomic trends may be sufficient for managing species at a large (national or regional) scale (Leidner and Neel, 2011). However, finding single populations and predicting population growth at smaller scales important for local planning initiatives may require quantitative information and many still argue that quantitative data are necessary for creating large scale predictive models (Newton, 2010). Similarly, misidentifying the center of a population, as often happens for highly dispersed populations, can result in missed individuals in later surveys and false 
absence data. This often results in qualitative information being used in reports, limiting spatial modeling capabilities (Engler et al., 2004). Population trajectories (recovering, declining, or neutral) are unknown for many species (Gordon et al., 1997) and reports often lack information directly cited as needed by the recovery objectives in the strategy document. Sometimes, educated estimates stand in place of actual quantitative data or the parameter is simply left out. This is particularly true for abundance estimates (Tear et al., 1995). Assessing recovery success and evaluating the success of conservation programs is therefore subject to a lack of reliable data (Male et al., 2006).

\subsection{Methods Currently Used to Find and Collect Data from Plant Populations}

\subsubsection{Species Specific Information}

Information about plant population distributions and abundances comes from many sources including formal survey work by scientists, happenstance findings from amateur naturalists, and indigenous and traditional knowledge. General knowledge of landscapes comes largely from amateur and traditional sources, with more information being held in aboriginal knowledge transfers than previously thought (Karst, 2010). Traditional-to-scientific sharing is being facilitated more throughout Canada as scientists realize the potential of having a qualitative base understanding of natural processes (Jacqmain et al., 2012). Implementing national conservation programs however, where there are specific criteria to implement in achieving national goals, requires detailed quantitative estimates of population distributions and abundances (Justice Laws, 2002). 


\subsubsection{Technical Approaches to Data Collection}

When designing formal surveys, the size and heterogeneous nature of the study area must be considered. Comprehensive surveys of small areas, for example, may use quadrats, smalls grid which themselves can be subdivided into small or large sections depending on the detail needed. These achieve highly detailed information for a small area. Quadrat size is important in determining survey type, as investigators must compromise between trying to reduce error, save time, and obtain high representation (Archaux et al., 2007). In some cases plot size may be best varied across the study area to achieve the best results, given resource constraints and a desire for large sample size (Barnett and Stohlgren, 2003). The total area covered and distribution of quadrats must also be taken into account, as randomness may be important (Hatcher et al., 1999). In most cases where a species is nationally important though, other techniques must be used for searching larger areas. Quadrats can be arranged in continuous lines, called transects, so that the total area covered by the survey increases. However, this technique still requires that the whole quadrat be inventoried, requiring a lot of time spent at groundlevel identifying species and counting individuals. Other transect-based techniques use line-of-sight as the only on-site search method, effectively reducing the width of the transect while increasing the total length. This may include biased or unbiased treatments and random or targeted distributions, and for at-risk species are usually centered around a predictor habitat (see Rew et al., 2006 for a review of these sampling techniques). The exact technique used often depends on the species and landscape under investigation but targeted transect methods are often employed for species at-risk. 
In an effort to curb spending and time devoted to searches, spatial modeling has become commonplace in species management both to identify areas of likely habitation for searching and also to estimate population parameters for the whole species based on a limited number of samples (Heppel et al., 2000; Holmes, 2001). Targeted surveys that make use, in tandem, of presence/absence data and environmental associations can be more effective at locating species of interest (Crall et al., 2013). Using line-of-sight, the surveyor might choose to collect data only from populations that are directly intersected by the transect. Or, when a population is encountered, the surveyor may conduct a radial scan of the surrounding area for other populations, and then another if an additional population is found, and so on, referred to as adaptive cluster sampling (Thompson, 1990; Roesch, 1993; Thompson, 2004; Conroy et al., 2008). Targeted transect surveys in general are popular for both invasive and at-risk species. The choice of exact survey method ultimately depends on species biology, landscape, and scope of the problem they are trying to resolve, so it is difficult to describe best practices. Furthermore, there are a number of difficulties encountered both in the field once a survey design is chosen and at the analysis stage when population characteristics must be estimated from a limited sample of the landscape.

\subsection{The Difficulties in Obtaining Accurate Data for Plant Populations}

\subsubsection{Resource Constraints Limit Resolution in the Field}

Plant survey efforts are inherently complicated by two factors; that it can be difficult to find populations in the first place, and also that plant species identification is often prone to error. All survey techniques are limited in their ability to detect individuals 
simply due to the complex natures of field science and large-scale environmental management. Firstly, plant identification requires expert knowledge that is limited in large field studies. Species that exist in a non-showy form over winter or that have cryptic morphologies, such as grasses and sedges, may be too difficult for even a seasoned botanist to identify confidently, requiring further morphological or genetic analysis (Buckland et al., 2007; Pang et al., 2011; Nock et al., 2011; Chakravarthy et al., 2008). Secondly, even a commonly used transect approach that takes place over a large area will compromise between the resources spent looking for the population and the precision with which the area is searched, meaning that small populations or those with patchy distributions, either in number of populations or number of individuals, may be missed entirely (Barry and Welsh, 2001; Melville and Welsh, 2001; Rew et al., 2006). Furthermore, even when populations do happen to be located by a survey, their characteristics are often not accurately recorded. Abundance estimates and geographical extent may be difficult to obtain for populations with highly dispersed individuals, populations that extend over a difficult or dangerous terrain to work in, and when search scale is large (MacKenzie et al., 2005). For missed populations, the issue is representation, while for those that are found, the issue then becomes accurate estimation of population parameters.

While spatial modeling for targeting search areas does reduce the time and effort needed for plant surveys in some cases, these models often require that biological information for the species be known to the investigator (Guisan et al., 2006), environmental variables be known across the entire landscape (Rew et al., 2005), a large sample size be present, and that sampling be done randomly (Araujo and Guisan, 2006; 
Fortin et al., 1989). These conditions are rarely met in reality and, as a result, spatial models tend to be prone to bias (Franklin, 1995). As the vast majority of surveys for important plant species are not random, models that attempt to target areas for searching must subsample to reduce bias and ultimately end up reducing sample size. Investigators can add additional samples from the landscape according to the spatial distribution wanted, but this can lead to a situation where even more surveying is needed to create a model to target more survey sites. Furthermore, because gathering abundance data even at a few sites for plant populations is so difficult, many models for distribution or habitat suitability are based on occurrence points, which do not necessarily represent population sizes (Bradley, 2013). These models therefore are not themselves giving a quantitative estimate of the abundance for each modeled population, but rather are helping to target additional surveys by estimating the likelihood of location, regardless of how many individuals might be at that location. In many cases population size may be crucial to prioritizing further investigation into the population, as the investigator may be more interested in either large or small populations. In these ways, resource constraints, whether financial, expertise-, or time-related, inevitably hamper the collection of highly representative field data for plant species at risk.

\subsubsection{Estimating Population Characteristics is Difficult When Data Availability is}

\section{Limited}

Models that do try to estimate abundances from a subsample of known populations are also subject to a number of statistical errors. Two-step target surveys (Thompson, 1992; Conroy et al., 2008) allow for the re-investigation of a subset of 
presence points to achieve abundance data, potentially allowing better prioritization of further survey work, but this requires at least two sampling days and assumes that a suitable presence signal was found during the first survey. This is a problem as targeted searches are the ones frequently used by conservation managers.

\subsubsection{There Has Been Limited Review or Application of Best Practices for Plant Survey Techniques}

Because there are so many options to choose from when designing a survey, there is little standardization in model or survey choice among land managers and no way to account for the differences in quality among data from different sources. Additionally, field data and modeled estimates are rarely reported with any estimation of error (Sleep and Trout, 2013). This is a problem not only for managers trying to interpret survey results but also for modelers who must use two sets of data in the same model but which were collected from different sources. Error is both common in field data collection and can be large for plant distribution and abundance values, because of the spatial issues outlined earlier.

In this way, whether it is through drawbacks in survey technique or the lack of standardization between investigators, resource constraints inevitably reduce the quality of field data. Given that models predicting future species distributions tend to be based on presence/absence data and that status designations often depend on quantitative population parameters (Jones et al., 2010; Engler et al., 2004; Potts and Elith, 2006), these surveying and identification difficulties may limit the credibility of management decisions made with such data. 


\subsection{The Consequences of Unreliable or Missing Conservation data}

The use of unreliable data can have serious consequences for species management. While there has been markedly less review in Canada, criticism for current application of the American Species at Risk Act is born out of a widely held belief that quantitative data, particularly for abundance measures, is necessary for informing effective conservation action. Confusion surrounding the quantitative population parameters of listed species may result in misrepresentation of true species status and inappropriate allocation of conservation dollars. SARA, in recognizing the importance of rare species to Canadian biodiversity and the economy, takes a precautionary approach to the management of listed species, stating that conservation attempts should not be foregone in the absence of scientific certainty of the status of the species (Sleep and Trout, 2013). The problem with this approach is twofold: one, species that are incorrectly prioritized may not be managed appropriately and therefore waste conservation dollars, negating the usefulness of a conservation governing body at all and, two, management efforts for species that are correctly prioritized may not be successful because they are not appropriately informed with accurate biological, ecological, or geographical knowledge. This stands in contrast to Canada's acknowledgement of the importance of at-risk species.

\subsection{Species Traits That May Reduce the Reliability of Survey Data}

Because we cannot easily improve the quality of plant population data, we must find ways of prioritizing species in light of the uncertainty surrounding their true status. This requires an understanding of why species are difficult to locate and assess, because 
species that are prone to surveying difficulty may be more likely to have misrepresented statuses. Therefore, conservation managers should be considerate of this relationship and prioritize species for management efforts accordingly. In many cases, these species may demand a more rigorous investigation into their true distribution and abundance, as the less intensive techniques used for other species may not suffice. Surveying difficulty is not often recorded by Canadian status reports, perhaps because surveys are always inherently difficult for the aforementioned reasons. However, there may be biological or ecological traits specific to certain species that may hint at whether surveys for those species are likely to produce unreliable data. For example, plant species can be evenly or patchily distributed, as a result of either natural or anthropogenic causes (fragmentation), and can also be small or large, again depending on natural and anthropocentric factors (Guisan et al., 1998; Bastin and Thomas, 1999; Moristia, 1959). Using the survey and estimation techniques outlined earlier, an investigator seems to be more likely to miss a population when patch size is small, the number of individuals is few, and patch distribution is highly fragmented and random (Fortin et al., 1989; Barry and Welsh, 2001; Melville and Welsh, 2001; Rew et al., 2006; Araujo and Guisan, 2006). Plant species atrisk tend to exist in such a pattern (Rew et al., 2005). Knowledge gaps in these areas may exist for a few reasons, one likely explanation being the serious survey inefficiencies that may affect the likelihood of finding and subsequently collecting data from plant populations. If this is the case, then these species need to be identified and managed accordingly. There may be biological or ecological traits common to these species that allows us to identify them as difficult to survey. 


\subsubsection{Ephemerality}

Ephemerality may affect the likelihood of finding a population in a plant survey if the target species has cryptic life history traits. This may be true for both surveys of known populations and targeted searches for new populations, based on the assumption that species that do not persist over winter, do not live for more than one year, or only exist in seed bank for long periods of time are more likely to be missed by a survey because they do not exist in showy form for as long as other species. For example, populations of herbaceous species, species that do not experience secondary woody growth, may be more difficult to find (and therefore more likely to be reported as missing) because they tend to be shorter lived over the season compared with woody species. Woody plants also have a characteristically effective advantage over herbaceous species in being able to resprout after a disturbance (Bellingham and Sparrow, 2000) and therefore may be regarded as more resilient than herbaceous plants. Plant size may be important here as well, as smaller plants even under healthy conditions tend not to live as long as larger species (Marba et al., 2007). It may be that herbaceous species are more likely to be missed in subsequent or new surveys because they are either small in size or do not exist in showy form over the winter season or a disturbance regime. Similarly, annual plants, which only live over the span of one year and reproduce once, may be more difficult to find because they are shorter lived than perennial plants, which may live and reproduce for many years. From a survey perspective, these situations produce false absence data. Ephemerality may be an important trait for identifying species more likely to yield unreliable data because it affects the likelihood of spotting individuals, either 
because they may not be noticeable when they are present or because they may be more likely to disappear.

\subsubsection{Susceptibility to Stochasticity}

Stochasticity may similarly influence the accuracy of a plant survey because it affects the longevity of population existence. Demographic stochasticity refers to the random variation in birth and death rates of individuals in a population. It is most effective in small isolated populations, which are more susceptible to change due to the lessened buffering effect of small numbers, called the rescue effect (McArthur and Wilson, 1967; Richter-Dyn and Goel, 1972). Populations with few individuals are more likely to decline dramatically in number because they cannot easily recover from the random incidence of a large number of deaths. They are also more susceptible to inbreeding, which may reduce overall fitness. Species at-risk are particularly susceptible to dramatic changes in population structure due to stochasticity because of their typically small population sizes (Schemske et al., 1994; Engen et al., 2003; Vindenes et al., 2008). Populations of fewer than 100 individuals are typically regarded as being at risk of extinction from stochasticity (Kokko and Ebenhard, 1996; Lande, 1994). Therefore, small populations may need to be surveyed more regularly to ensure they do in fact still exist. Furthermore, small populations that have not yet been discovered may remain unreported because they are less likely to be encountered in the first place and more likely to disappear before a survey intersects their former location. In this way, susceptibility to demographic stochasticity increases the level of uncertainty surrounding presence/absence data as well as abundance for species with small populations. 


\subsubsection{Geographical Isolation}

Spatial location may also affect the likelihood of collecting representative data. Habitat fragmentation often leads to population fragmentation in species at-risk (Lienert, 2004). Being highly fragmented from other populations is typically a result of unavailable habitat, which often means the population is going to stay isolated, as there is little opportunity for expansion. Furthermore, these populations, especially if they are small, tend to suffer from inbreeding depression, which may increase the degree of isolation as it reduces individual fitness (Baur et al., 1995; Boswell et al., 1998). For populations that are already known, this may mean they are more likely to disappear between surveys and, similar to species susceptible to demographic stochasticity, may require more frequent surveying to ensure accurate presence/absence data. When looking for new populations, geographically isolated populations are less likely to be encountered because, without neighbouring populations, there may be no reason to survey that area using adaptive survey techniques (Thompson, 1990; Roesch, 1993; Thompson, 2004; Conroy et al., 2008). Populations such as these, even if they are abundant in individuals, may be difficult to locate in the landscape because they are so widely distributed across the study area. That is, they may be said to have a large extent of occurrence but a small area of occupancy. Other species, like some large trees, may naturally exist in tiny populations of only one individual. In these cases, finding new populations would be a lot like searching for a needle in a haystack. Furthermore, species like these may be difficult to collect abundance data for because it may be difficult to tell where one breeding population ends and another begins. Individuals similarly may be missed because they are so widely separated from eachother. Either way, geographic isolation both increases 
the difficulty of accurately surveying a known population and reduces the likelihood of finding a new population, thereby reducing data reliability and placing the population at greater risk of extirpation as a result of faulty management.

\subsection{Objectives of This Study}

Prioritizing Canadian species for conservation management in light of the uncertainty surrounding their true status is a difficult task. Some species may be underrepresented or misrepresented as a result of surveying difficulty and therefore demand a more rigourous investigation into their true distribution and abundance before they can be properly assigned a status designation or evaluated for recovery objectives. In this thesis, I attempt to identify species for which there is a lack of reliable data. I further attempt to identify some predictor traits that may hint at whether a species is likely to report reliable population data or not, in the hope that this information may be used to target listed species for further investigation.

To achieve these goals, I first identify plant population parameters given by COSEWIC status reports that tend to have major gaps in abundance and distribution information by counting the number of missing entries in each. I specifically quantify the number of species for which there are unclear presence/absence data. To do this, I counted the number of species status reports that reported at least one population of uncertain existence. I then propose that there may be biological or ecological traits common to particular species that make them more or less difficult to survey in the field and suggest some traits that may lead to surveying difficulties and therefore a larger number of missing data points. These traits relate to surveying difficulty in the degree to 
which they affect species ephemerality, susceptibility to demographic stochasticity, and susceptibility to geographic isolation, as described above. To investigate this, I have related nine adapted quantitative parameters given by the status reports as well as three qualitative parameters to whether or not their species report a population of uncertain existence. These describe the abundance, distribution, and biology of the species and include: life span (annual or perennial), outer tissue type (herbaceous or woody), the ratio of area of occupancy to extent of occurrence, the number of populations, average population size, average geographical population size, minimum and maximum number of individuals in a single population, and total population fragmentation (severely fragmented or not fragmented).

If there are species-specific parameters that increase the difficulty of surveying populations of that species, then we should see a relationship in the species that have these traits and the likelihood that their reports will report populations of uncertain existence. Furthermore, these species may also be more likely to report missing data in other parameters as well. If there are not, then I have at least identified listed species for which there is a lack of information cited as crucially needed by COSEWIC's mandate and the goals outlined by many Canadian recovery strategies. My results describe the state of Canadian status reports in terms of these indicators and attempt to answer the following questions:

- Question 1: Which population parameters described in these reports are missing needed information (blank entries or "unknown" entries in parameters describing abundance, distribution, and biological traits)? 
- Question 2: What proportion of species at-risk listed in Canada have at least one population of uncertain status/existence? How many populations of uncertain status do these species have on average?

- Question 3: Are some species more likely to have missing information than others because of similar biological or ecological characteristics?

3A: Are annual and herbaceous species more likely to be missing information in status reports or have populations of uncertain status in status reports than perennial and woody species?

3B: Are species with small populations more likely to be missing information in status reports or have populations of uncertain status than species with relatively large populations?

3C: Are species with dispersed populations in fragmented landscapes more likely to be missing information in status reports or have populations of uncertain status than species whose populations are clumped or exist in non-fragmented landscapes?

3D: Generally, are species that lack basic conservation information more likely to have or have populations of uncertain status than species with relatively complete conservation information? 


\section{METHODS}

I retrieved information on at-risk plant species in Canada from the Canadian Species at Risk Act Registry (SARA) / COSEWIC Status Reports to create a Canadian database for plant species at risk. For each species I have recorded the number of populations with known versus uncertain status as well as data points pertaining to abundance (as it relates to demographic stochasticity), distribution (as it relates to isolation), and species biology (as it relates to ephemerality). All species with recorded report traits can be found in Appendix A. To address my objectives, I summarize these report parameters and then outline a series of ANCOVA tests to compare the degree of missing information in these parameters to species-specific traits.

\subsection{COSEWIC Status Reports in 2013}

In the 2003-2008 Species at Risk Act General Status Report, 110 of the 3858 naturally occurring vascular plant species in Canada were listed as "At Risk". An additional 552 species were listed as "May Be At Risk", 112 were listed as "Undetermined", and 30 were listed as "Not Assessed" (Environment Canada, 2009). All together, these largely unexamined species made up approximately $18 \%$ of the total number of Canadian vascular species according to the report. On COSEWICs registry website (http://www.sararegistry.gc.ca) in August 2013, there were 172 vascular plant species listed within the Species at Risk Registry including 29 with Special Concern designation. In April 2014 there were 213 species listed including 66 Special Concern or Not At Risk. Some of these species may have been added to the list since the 2008 publication from the may be at risk, undetermined, or not assessed categories. My 
analyses are limited to the data available in 2013 but it is important to note that these numbers have changed. I excluded the 29 species of Special Concern from my dataset because they were less likely to remain in their current status designation over the multiple years this study took place. Therefore, if the decision was made to continue these analyses with next years' data, these species would be less likely to offer useful information. Additionally, nineteen reports for Endangered or Threatened species were either unavailable or incomplete, having no report available on the SARA registry or having missing sections in a report that was available, resulting in a final sample size of 103 species. Ultimately, I extracted data from 103 COSEWIC status reports for species that were listed as Believed Extirpated, Endangered, or Threatened. In each status report I explicitly searched for information in the Biology section and Technical Summary of each Status Report to collect species distribution and abundance estimates.

\subsection{Standardization of Data Collected from COSEWIC Status Reports}

For each species, I recorded the number of known and uncertain populations from the technical summary of the status reports. I next recorded the quantitative and qualitative parameters that characterize ephemerality, susceptibility to demographic stochasticity, and geographical isolation, described below. To ensure consistent interpretation of the information provided, data were extracted and manipulated by the same method for each report. Where values were given in a range, I recorded the highest value. For example, a total population size estimate of 1000-1500 would have been recorded as 1500 individuals. By convention, area of occupancy must not exceed extent of occurrence in COSEWIC reports. In cases where there was only one population 
present, I assumed the extent of occurrence to equal the area of occupancy, even if stated otherwise in the report. This choice was based on the observation that reported extents were based either on grid estimations (that were not as precise as the measured area of occupancy) or on measurements including the locations of uncertain populations. I distinguished between populations of known versus uncertain status. In some reports, the number of populations of uncertain status was presented as its own parameter (called uncertain populations). In others, however, the total number of known populations was given as a range and the uncertain populations parameter left blank. In these cases the low value was used to represent the known populations and the difference between low and high values was used to represent uncertain locations. When report authors did not mention the uncertain population parameter, but instead only recorded the known number of populations as a single numerical entry while leaving the uncertain parameter blank, I interpreted this to mean that the report is certain of all possible populations for that species and left a blank for populations of uncertain status. The number of uncertain populations was never given as a zero in the status reports and I did not record them as such either, instead my blank entries represent missing data. I recognize that these are assumptions and my dataset represents a minimum estimate of the degree of uncertainty in population data. All summary statistics inevitably included some blank entries, as not all species reports contained every piece of information I was looking for. These were recorded differently from entries where "unknown" was reported by COSEWIC. However in the analyses both entries were treated as missing data or as a value of zero, depending on the question. I summarized each original or calculated variable according 
to the nature of the extracted data. Qualitative data were summarized in counts while averages, medians, and errors were calculated for quantitative data.

\subsection{Data Collection and Analysis by Question}

\subsubsection{Question 1: Which Population Parameters Are Missing Information?}

I recorded whether the species was perennial or annual as well as herbaceous or woody, from the descriptive paragraphs of the Biology section of the Status Reports. Biennial species were included with perennial species. Biennial species were recorded as perennials. I recorded the following data parameters from the Technical Summary of each report to describe population-level susceptibility to demographic stochasticity: total number of mature individuals in Canada, number of populations, area of occupancy, and number of individuals for a single population (minimum and maximum). In addition to these, I calculated an additional parameter to characterize the average population size by dividing the total number of individuals by the number of populations. To characterize the average geographical area, I divided the area of occupancy by the total number of populations for each species, assuming that this would represent the area of occupancy for a single average population. I also recorded data from the Technical Summaries to describe geographical isolation. These included extent of occurrence, area of occupancy, and qualitative descriptions of fragmentation. I also calculated an additional parameter to describe the proportion of range occupied (the proportion of the range all populations together actually take up), by dividing the area of occupancy by the extent of occurrence. To determine which parameters had large gaps in knowledge, I summarized each by the number of missing data points. 


\subsubsection{Question 2: What Proportion of Species Have At Least One Population of}

\section{Uncertain Status/Existence? How Many Populations of Uncertain Status Do These Species Have On Average?}

I recorded the number of current populations (what I call known) and the number of uncertain populations (what I call populations of uncertain status or missing populations) from the Technical Summary of the Status Reports. The number of uncertain populations was inferred either directly from the report parameter "number of uncertain populations" or indirectly from an estimate of "known populations" given in a range, as described above. For example, in a situation where the number of known populations was cited as 10-12 and the number of uncertain populations was left blank, I interpreted that to mean there were 10 certain populations and 2 uncertain. To determine the prevalence of missing populations, I calculated summary statistics across species, comparing those that had at least one population of uncertain status versus those species for which there were no reported populations of uncertain status and how many of these populations they reported. I used this parameter below in additional statistical analyses.

\subsubsection{Question 3: Are Some Species More Likely to Have Missing Information?}

\subsubsection{Are Particular Species More Likely to Report Missing Data Points in Report}

\section{Parameters For Some Common Reason?}

To determine whether missing data can be predicted by traits related to species ephemerality, susceptibility to demographic stochasticity, and susceptibility to geographical isolation, I ran a series of Poisson distribution ANCOVA tests using SPSS 
Statistics 21 (1989, 2012; SPSS Inc., Chicago Illinois USA). I used a Poisson distribution in response to finding non normal distributions for my parameters of interest. I made number of missing data points the response variable and a number of report parameters the independent variables: life span, tissue type, fragmentation, as fixed factors and the proportion of the range occupied (AO/EO) as covariate. I initially included all parameters examined in this study but found this combination produced the best model. For these two questions only, I added information to the dataset that was originally missing from the status reports, as described earlier, from the USDA PLANTS database (USDA, 2014). This was done to maximize the availability of information on predictor traits. The number of missing data points however, which was analyzed by the procedure below, was kept constant with the initial assessment, before gaps were filled in with outside information.

\subsubsection{Are Particular Species More Likely to Report Missing Populations For Some Common Reason?}

To determine whether missing populations can be predicted by traits related to species ephemerality, susceptibility to demographic stochasticity, and susceptibility to geographical isolation, I ran a series of Poisson distribution ANCOVA tests using SPSS Statistics 21 (1989, 2012; SPSS Inc., Chicago Ilinois USA) identical to the analysis for missing data. I made number of missing populations the response variable and a number of report parameters the independent variables: life span, tissue type, fragmentation, as fixed factors and the proportion of the range occupied as covariate (AO/EO). 
Concerning data describing ephemerality, I predicted that herbaceous and annual species would be more likely to report uncertain populations because they are difficult to find, compared with woody and perennial species. With this premise, I asked whether species with at least one population of uncertain status differed in a significant way in life history traits (annual or perennial and herbaceous or woody) from species that did not report such populations. I did the same comparing tissue type with whether species reported uncertain populations or not. Concerning data describing susceptibility to demographic stochasticity, I predicted that species with small population sizes would be more likely to report uncertain populations under the assumption that these populations are more likely to be missed during surveys when they are present and are also more likely to die out between surveys due to stochastic processes. I asked whether species with at least one uncertain population differed in their average population size (abundance) of one population from species that did not report any uncertain populations. Concerning data describing geographic isolation, I predicted that species with small geographical area would be more likely to report uncertain populations, again, under the assumption that these populations are more likely to be missed during surveys when they are present and are also more likely to die out between surveys. I predicted that species with a small $\mathrm{AO} / \mathrm{EO}$ (proportion of range individuals actually take up in space) would be more likely to report uncertain populations because they may either exist in isolated groups or be very small in size, reducing the likelihood of being found in a survey. I also predicted that species reporting severe population fragmentation would be more likely to report uncertain populations based on the assumptions that isolated populations are more difficult to locate when searching for new sites and that known populations are more 
likely to die out between surveys. I asked whether species with at least one uncertain population differed in population fragmentation from species that did not report uncertain populations. 


\section{RESULTS}

\subsection{Question 1: Which Population Parameters Are Missing Information?}

\subsubsection{Biological Information}

Of the 103 species studied, $31(30 \%)$ were annual and $63(61 \%)$ were perennial; Status reports for nine species did not report life-span (see Table 1 and raw data in Appendix A). Upon further investigation, I found that these nine species were comprised of entirely of perennial plants. Further, 80 (78\%) species were herbaceous and 7 (7\%) were woody; 16 species reports did not report tissue type (Figure 1). Again, upon further investigation, I found that these 16 species were comprised of 15 herbaceous and 1 woody species. Of the annual species, 29 were herbaceous while two were woody and one was missing an entry. Of perennial species, 48 were also herbaceous while six were woody and eight did not report the parameter. There were seven species that did not contain information for either life history parameter. 


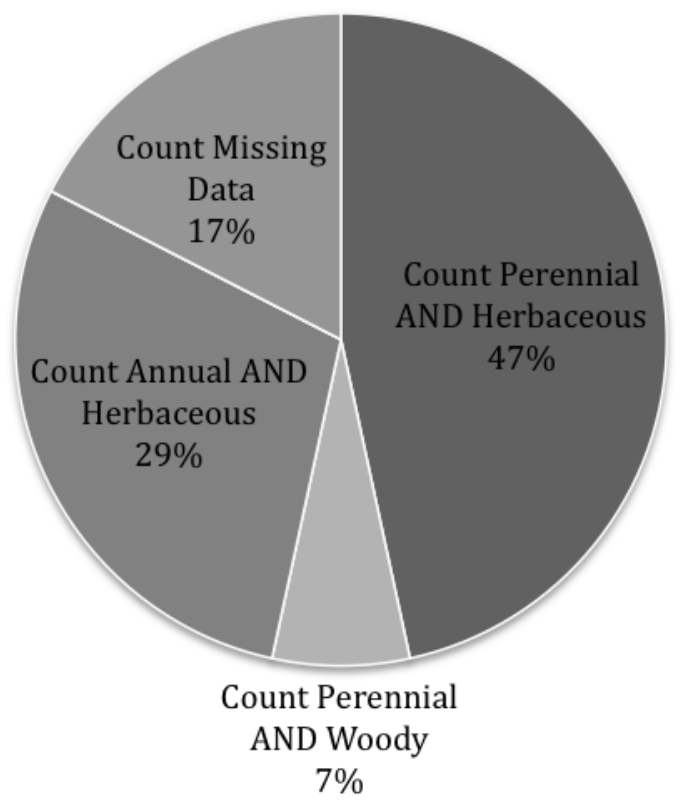

Figure 1. Summary of ephemerality traits for COSEWIC-listed plant species Status Reports. Data includes 103 species from the SARA registry. Perennial species includes true perennials and biennials.

\subsubsection{Abundance Information}

Average population size was $170,609 \pm 1,259,469$ individuals $(\mathrm{N}=92$, Median $=$ 392, Minimum $=0$; Maximum $=12000000)$. Seven reports $(7 \%)$ did not record the total number of mature individuals for the species, seven (7\%) did not record area of occupancy, and $39(38 \%)$ and $37(36 \%)$ did not record min and max number of individuals per population, respectively (see Table 1).

\subsubsection{Distribution Information}

Average geographical population area was $2.18 \mathrm{~km}^{2} \pm 4.22^{2}(\mathrm{~N}=96$, Median $=$ $0.5 \mathrm{~km}^{2}$, Minimum $=0 \mathrm{~km}^{2}$, Maximum $=20 \mathrm{~km}^{2}$ ). On average, populations occupied $20.89 \% \pm 0.36 \%$ of their range $(\mathrm{AO} / \mathrm{EO}: \mathrm{N}=95$, Median $=.2 .46 \%$, Minimum $=$ 
$0.0006 \%$, Maximum $=100 \%$ ). Fifty-one species $(50 \%)$ were reported as having a severely fragmented distribution, 25 (24\%) were not considered severely fragmented, and 27 species lacked information.

\subsubsection{Summary of Missing Information}

Most species were missing only one or two parameters out of the nine chosen for this study. Together this produced a total of 137 missing data points. Fifty-eight percent of that is attributable to missing abundance estimates, twenty-four percent to geographical information, and eighteen to biological information (see Figure 2 and 3, Table 1, and Table 2). 


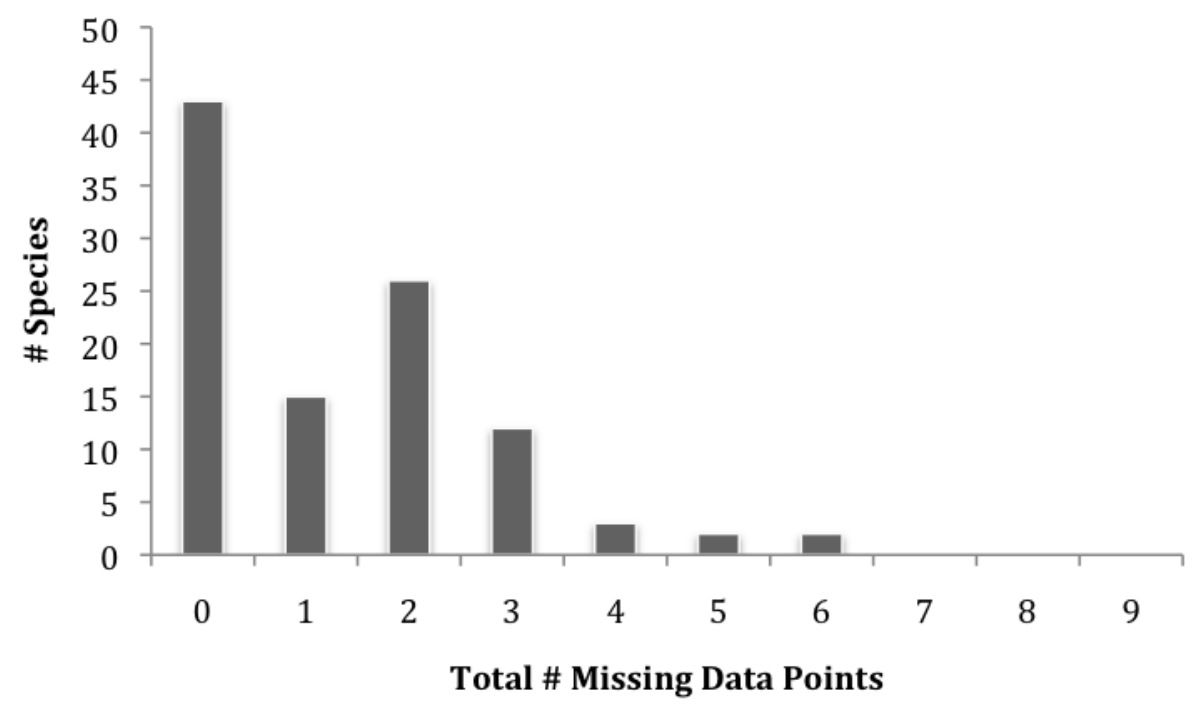

Figure 2. Frequency of COSEWIC status reports for plant species exhibiting missing data points (blank or unknown entries). These include life span, tissue type, extent of occurrence, area of occupancy, number of known populations, total number of individuals in Canada, minimum and maximum number of individuals in a single population, and fragmentation.

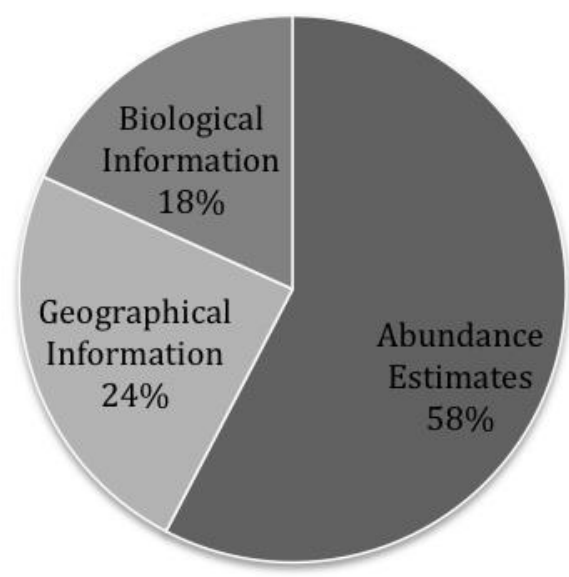

Figure 3. Distribution of missing data in COSEWIC-listed plant species status reports by parameter type. There were 137 missing parameters within 103 species. Abundance estimates were described by total number of individuals, minimum number of individuals in a population, and maximum number of individuals in a population. Geographical information was described by extent of occurrence, area of occupancy, and degree of fragmentation, and biological information was described by life history and tissue type. 
Table 1. Summary of parameter values for 103 COSEWIC-listed plant species with available status reports in 2013. These include life span, tissue type, extent of occurrence, area of occupancy, number of known populations, total number of individuals in Canada, minimum and maximum number of individuals in a single population, and fragmentation.

\begin{tabular}{|c|c|c|c|c|}
\hline Trait & $\begin{array}{l}\text { Mean or summary } \\
\text { (across all species) }\end{array}$ & SE & Median & $\begin{array}{l}\text { n (out of } \\
103 \\
\text { species) }\end{array}$ \\
\hline Life span & 63 perennial, 31 annual & $\mathrm{n} / \mathrm{a}$ & $\mathrm{n} / \mathrm{a}$ & 94 \\
\hline Tissue type & 80 herbaceous, 7 woody & $\mathrm{n} / \mathrm{a}$ & $\mathrm{n} / \mathrm{a}$ & 87 \\
\hline Extent of Occurrence (EO) & 4866.13 & 149.31 & 77 & 97 \\
\hline Area of Occpupancy (AO) & 23.86 & 0.59 & 5 & 95 \\
\hline $\mathrm{AO} / \mathrm{EO} * 100$ & 20.89 & 0.36 & 2.46 & 95 \\
\hline $\begin{array}{l}\text { Number of known } \\
\text { populations }\end{array}$ & 10.5 & 0.2 & 5 & 103 \\
\hline $\begin{array}{l}\text { Number of missing } \\
\text { populations }\end{array}$ & 2.19 & 0.12 & 1 & 21 \\
\hline $\begin{array}{l}\text { Total number of } \\
\text { individuals in Canada }\end{array}$ & $514,475.91$ & $22,339.98$ & $1,650.00$ & 96 \\
\hline $\begin{array}{l}\text { Average Population Size } \\
\text { (total/\#pops) }\end{array}$ & $170,609.76$ & $12,689.89$ & 392.31 & 92 \\
\hline $\begin{array}{l}\text { Average Geog. Population } \\
\text { Size (AO/\#pops) }\end{array}$ & 2.18 & 0.04 & 0.5 & 96 \\
\hline $\begin{array}{l}\text { Minimum number of } \\
\text { individuals in a single } \\
\text { population }\end{array}$ & 891.95 & 74.89 & 37.5 & 64 \\
\hline $\begin{array}{l}\text { Maximum number of } \\
\text { individuals in a single } \\
\text { population }\end{array}$ & $331,303.97$ & $27,199.89$ & $1,287.00$ & 66 \\
\hline Fragmentation & $\begin{array}{l}51 \text { severely fragmented, } \\
29 \text { not fragmented }\end{array}$ & $\mathrm{n} / \mathrm{a}$ & $\mathrm{n} / \mathrm{a}$ & 80 \\
\hline
\end{tabular}


Table 2. The number of missing parameter values for COSEWIC-listed at-risk plant species status reports and the details of which values were missing in the sections reviewed of each status report (Technical report, biology section). Species missing more than three pieces of data critical to conservation action $(n=20)$ are highlighted with grey shading. . Missing data categories include: $\mathrm{AO}=$ Area of Occupancy, EO = Extent of Occuurence, $\mathrm{F}=$ fragmentation, $\mathrm{LS}=$ life span, $\mathrm{MAX}=$ population size of the largest known population, $\mathrm{MIN}=$ population size of the smallest known population, $\mathrm{TN}=$ total number of mature individuals in Canada, and TT - tissue type. Number of known populations was not missing for any species.

\begin{tabular}{|c|c|c|}
\hline Scientific name & $\begin{array}{c}\text { Number } \\
\text { of Blank } \\
\text { Entries }\end{array}$ & Missing parameters \\
\hline Actaea elata & 0 & \\
\hline Agalinis skinneriana & 0 & \\
\hline Ammannia robusta & 0 & \\
\hline Antennaria Flagellaris & 0 & \\
\hline Betula lenta & 0 & \\
\hline Camissonia contorta & 0 & \\
\hline Carex tumulicola & 0 & \\
\hline Celtis tenuifolia & 0 & \\
\hline Dalea villosa & 0 & \\
\hline Enemion biternatum & 0 & \\
\hline Eurybia divaricata & 0 & \\
\hline Juncus kelloggii & 0 & \\
\hline Liatris spicata & 0 & \\
\hline Liparis liliifolia & 0 & \\
\hline Lipocarpha micrantha & 0 & \\
\hline Lotus formosissimus & 0 & \\
\hline Lotus pinnatus & 0 & \\
\hline Lupinus densiflorus & 0 & \\
\hline
\end{tabular}




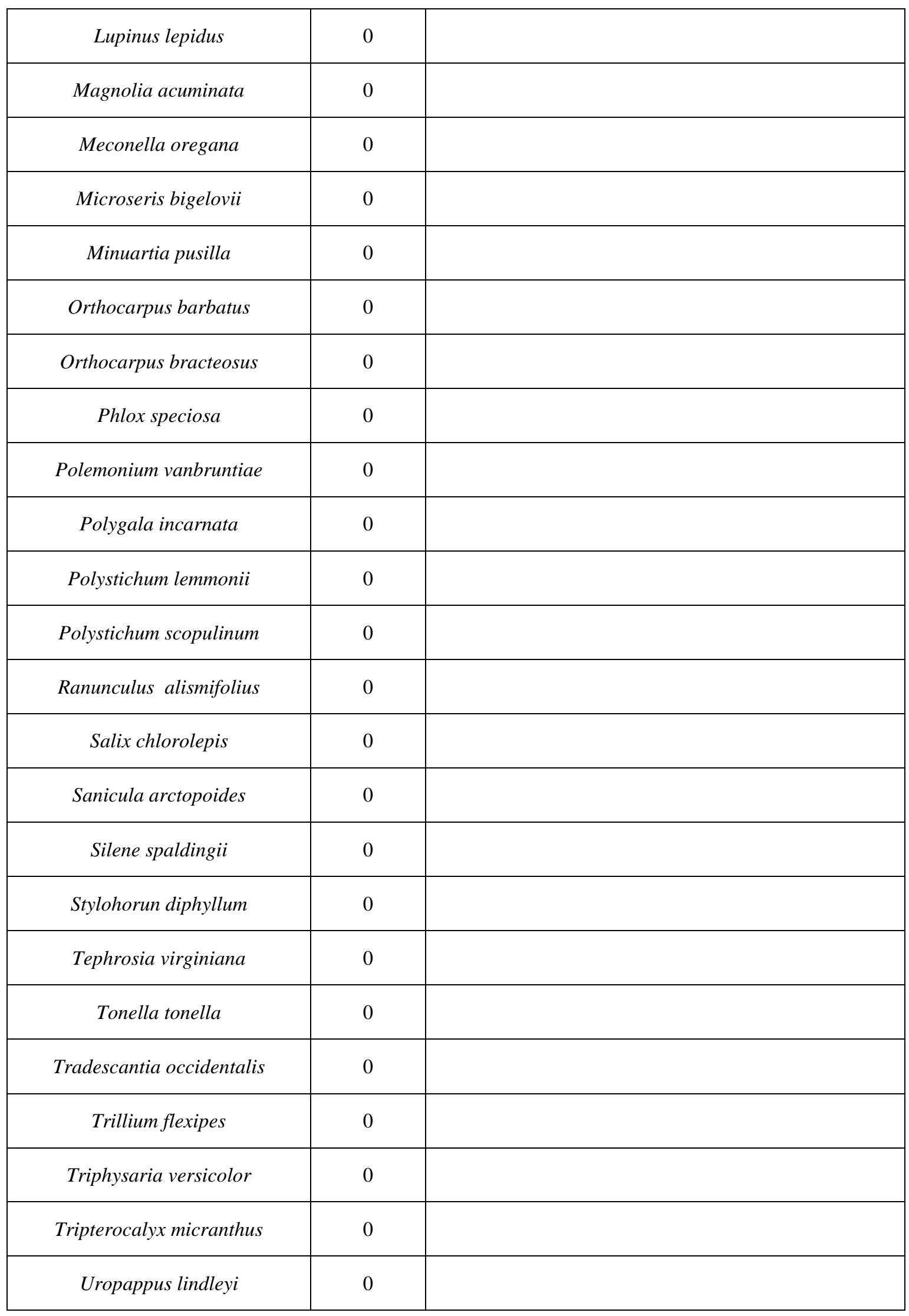




\begin{tabular}{|c|c|c|}
\hline Viola praemorsa ssp. praemorsa & 0 & \\
\hline Buchnera americana & 1 & TT \\
\hline Calochortus lyallii & 1 & TT \\
\hline Camassia scilloides & 1 & $\mathrm{~F}$ \\
\hline Carex juniperorum & 1 & TT \\
\hline Castilleja levisecta & 1 & $\mathrm{~F}$ \\
\hline Castilleja rupicola & 1 & LS \\
\hline Castilleja victoriae & 1 & $\mathrm{AO}$ \\
\hline $\begin{array}{c}\text { Eleocharis geniculata (great lake } \\
\text { plains) }\end{array}$ & 1 & $\mathrm{~F}$ \\
\hline Lophiola aurea & 1 & $\mathrm{~F}$ \\
\hline Phacelia ramosissima & 1 & TT \\
\hline Plagiobothrys tenellus & 1 & $\mathrm{~F}$ \\
\hline Psilocarphus brevissimus & 1 & $\mathrm{TN}$ \\
\hline Ptelea trifoliata & 1 & TT \\
\hline Sanicula bipinnatifida & 1 & $\mathrm{~F}$ \\
\hline Triteleia howellii & 1 & $\mathrm{AO}$ \\
\hline Abronia umbellata & 2 & MAX, MIN \\
\hline Adiantum capillus-veneris & 2 & $\mathrm{EO}, \mathrm{AO}$ \\
\hline Agalinis aspera & 2 & MAX, MIN \\
\hline Azolla mexicana & 2 & MAX, MIN \\
\hline Bouteloua dactyloides & 2 & MAX, MIN \\
\hline Carex lupuliformis & 2 & MAX, MIN \\
\hline
\end{tabular}




\begin{tabular}{|c|c|c|}
\hline Carex sabulosa & 2 & LS, TT \\
\hline Castanea dentata & 2 & MAX, MIN \\
\hline Centaurium muehlenbergii & 2 & MAX, MIN \\
\hline Chenopodium subglabrum & 2 & MAX, MIN \\
\hline Cirsium hillii & 2 & MAX, MIN \\
\hline Collomia tenella & 2 & MAX, MIN \\
\hline Drosera filiformis & 2 & MAX, MIN \\
\hline Gentiana alba & 2 & MAX, MIN \\
\hline Geum peckii & 2 & LS, TT \\
\hline Isoetes bolanderi & 2 & MAX, MIN \\
\hline lupinus rivularis & 2 & MAX, MIN \\
\hline Plantago cordata & 2 & LS, TT \\
\hline Platanthera leucophaea & 2 & MAX, MIN \\
\hline Ranunculus Californicus & 2 & $\mathrm{~F}, \mathrm{LS}$ \\
\hline Sida hermaphrodita & 2 & MAX, MIN \\
\hline Silene Scouler ssp.grandis & 2 & MAX, MIN \\
\hline Symphyotrichum frondosum & 2 & MAX, MIN \\
\hline Symphyotrichum praeltum & 2 & MAX, MIN \\
\hline Woodsia obtusa & 2 & MIN, TT \\
\hline Triphora trianthophoros & 3 & MAX, MIN, TN \\
\hline Balsamorhiza deltoidea & 3 & MAX, MIN, TN \\
\hline
\end{tabular}




\begin{tabular}{|c|c|c|}
\hline Cirsium pitcheri & 3 & F, MAX, MIN \\
\hline Cornus florida & 3 & F, MAX, MIN \\
\hline Cryptantha minima & 3 & MAX, MIN, TN \\
\hline Frasera caroliniensis & 3 & MAX, MIN, TT \\
\hline Hymenoxys herbacea & 3 & MAX, MIN, TT \\
\hline Isoetes engelmannii & 3 & $\mathrm{~F}, \mathrm{LS}, \mathrm{TT}$ \\
\hline Lomantium grayi & 3 & F, LS, TT \\
\hline Smilax rotundifolia & 3 & F, MAX, MIN \\
\hline Symphyotrichum Laurentianum & 3 & F, MAX, MIN \\
\hline Symphyotrichum prenanthoides & 3 & F, MAX, MIN \\
\hline Viola pedata & 3 & F, MAX, MIN \\
\hline $\begin{array}{l}\text { Bartonia paniculata ssp. } \\
\text { paniculata }\end{array}$ & 4 & F, MAX, MIN, TT \\
\hline Epilobium torreyi & 4 & AO, EO, MAX, MIN \\
\hline Potamogeton ogdenii & 4 & AO, EO, MAX, MIN \\
\hline Plagiobothrys figuratus & 5 & $\mathrm{AO}, \mathrm{EO}, \mathrm{F}, \mathrm{MAX}, \mathrm{MIN}$ \\
\hline Vaccinium stamineum & 5 & F, LS, MAX, MIN, TT \\
\hline Isotria medeoloides & 5 & F, LS, MAX, MIN, TT \\
\hline Lupinus oreganus & 6 & AO, EO, MAX, MIN, TN \\
\hline
\end{tabular}




\subsection{Question 2: What Proportion of Species Have At Least One Population of Uncertain Status? How Many Populations of Uncertain Status Do These Species Have On Average?}

Of the 103 species studied, $21(20 \%)$ contained at least one population of uncertain status (range $=0-10$ uncertain populations, Figure 4). When species had uncertain populations, on average, uncertain populations made up $37 \% \pm 21 \%$ (assuming blank entries for uncertain populations had a value of zero) of the total number of populations known or speculated to exist for each species (median $=25 \%$, Figure 5). The proportion of uncertain to known populations (percent total species missing) ranged from

$8 \%(\mathrm{n}=3)$ to $100 \%(\mathrm{n}=4$, these species are assumed extirpated $)$. Species were summarized by parameter value, comparing species with missing populations and those not reporting missing populations, in Table 3. I explore differences between these groups below. 


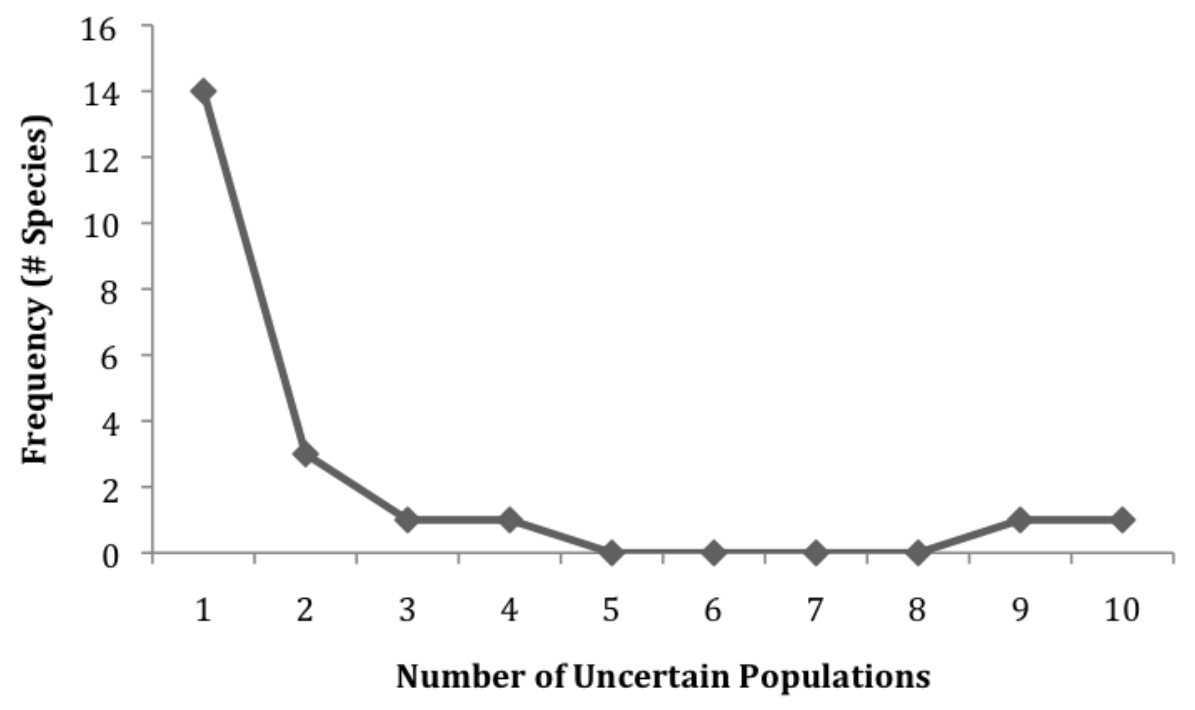

Figure 4. Frequency of uncertain populations among COSEWIC-listed plant species status reports with at least one uncertain population. $\mathrm{N}=103$ species.

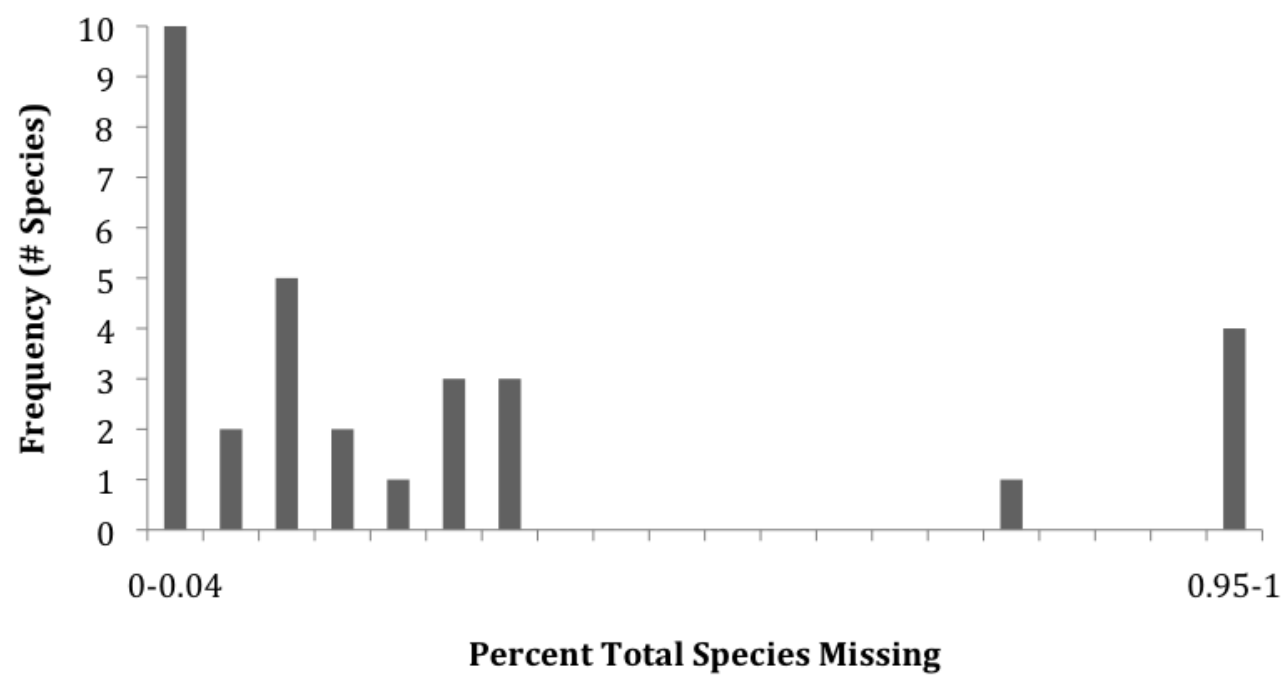

Figure 5. Frequency of the proportion of uncertain populations among COSEWIC-listed species status reports with at least one uncertain population. $\mathrm{N}$ $=103$ species. The value for the first bar is off the chart at 84 species. 
Table 3. Summary of parameter values (Mean, Standard Error (SE), and Median) for both species reporting populations of uncertain status and species not reporting populations of uncertain status. Qualitative traits are presented first followed by quantitative. $\mathrm{N}=103$. Proportion of range occupied was calculated as AO/EO*100, Average Population Size was calculated as total \# individuals / \# populations, and Average Geog. Population Size was calculated as $\mathrm{AO} /$ \# populations.

\begin{tabular}{|c|c|c|c|c|c|c|}
\hline Trait & $\begin{array}{c}\text { Mean or } \\
\text { Count of } \\
\text { Species with } \\
\text { No Uncertain } \\
\text { Populations }\end{array}$ & SE & Median & $\begin{array}{c}\text { Mean or } \\
\text { Count of } \\
\text { Species with } \\
\text { 1+ Uncertain } \\
\text { Populations }\end{array}$ & SE & Median \\
\hline Life span & $\begin{array}{l}50 \text { perennial, } \\
26 \text { annual }\end{array}$ & $\mathrm{n} / \mathrm{a}$ & $\mathrm{n} / \mathrm{a}$ & $\begin{array}{c}13 \text { perennial, } 5 \\
\text { annual }\end{array}$ & $\mathrm{n} / \mathrm{a}$ & $\mathrm{n} / \mathrm{a}$ \\
\hline Tissue type & $\begin{array}{l}64 \text { herbaceous, } \\
6 \text { woody }\end{array}$ & $\mathrm{n} / \mathrm{a}$ & $\mathrm{n} / \mathrm{a}$ & $\begin{array}{c}16 \text { herbaceous, } \\
1 \text { woody }\end{array}$ & $\mathrm{n} / \mathrm{a}$ & $\mathrm{n} / \mathrm{a}$ \\
\hline Fragmentation & $\begin{array}{l}42 \text { severely } \\
\text { fragmented, } \\
22 \text { not }\end{array}$ & $\mathrm{n} / \mathrm{a}$ & $\mathrm{n} / \mathrm{a}$ & $\begin{array}{c}9 \text { severely } \\
\text { fragmented, } 7 \\
\text { not }\end{array}$ & $\mathrm{n} / \mathrm{a}$ & $\mathrm{n} / \mathrm{a}$ \\
\hline $\begin{array}{c}\text { Extent of } \\
\text { Occurrence (EO) }\end{array}$ & $3,461.08$ & 136.34 & 70.00 & $11,979.22$ & $1,565.40$ & 778.50 \\
\hline $\begin{array}{c}\text { Area of } \\
\text { Occpupancy (AO) }\end{array}$ & 19.03 & 0.55 & 4.05 & 49.66 & 6.30 & 8.00 \\
\hline $\begin{array}{c}\text { Proportion of } \\
\text { range occupied }\end{array}$ & 22.19 & 0.44 & 2.56 & 13.92 & 1.86 & 2.46 \\
\hline $\begin{array}{c}\text { Number of known } \\
\text { populations }\end{array}$ & 11.40 & 0.28 & 5.00 & 7 & 0.36 & 4.00 \\
\hline $\begin{array}{l}\text { Number of } \\
\text { missing } \\
\text { populations }\end{array}$ & $\mathrm{n} / \mathrm{a}$ & $\mathrm{n} / \mathrm{a}$ & $\mathrm{n} / \mathrm{a}$ & 2.19 & 0.12 & 1.00 \\
\hline $\begin{array}{l}\text { Total number of } \\
\text { individuals in } \\
\text { Canada }\end{array}$ & $643,202.53$ & $31,535.29$ & $1,650.00$ & $25,314.70$ & $3,604.00$ & 1631.50 \\
\hline $\begin{array}{c}\text { Average } \\
\text { Population Size }\end{array}$ & $214,100.60$ & $19,351.19$ & 416.67 & $3,513.41$ & 598.26 & 350.00 \\
\hline $\begin{array}{l}\text { Average Geog. } \\
\text { Population Size }\end{array}$ & 2.10 & 0.05 & 0.50 & 2.5 & 0.27 & 0.42 \\
\hline $\begin{array}{l}\text { Minimum number } \\
\text { of individuals in a } \\
\text { single population }\end{array}$ & 1037.77 & 102.11 & 44.50 & 260.083 & 46.79 & 33.00 \\
\hline $\begin{array}{c}\text { Maximum } \\
\text { number of } \\
\text { individuals in a } \\
\text { single population }\end{array}$ & $408,137.17$ & $37,724.07$ & $1,274.00$ & $18,060.92$ & $2,980.14$ & 1300.00 \\
\hline
\end{tabular}




\subsection{Question 3: Are Some Species More Likely to Have Missing Information? Are Particular Species More Likely to Report Missing Data Points in Report Parameters For Some Common Reason? Are Particular Species More Likely to Report Missing Populations For Some Common Reason?}

Biological, demographic, and life history traits did not predict the degree to which data was missing in status reports. However, missing data points in these species-level characteristics, did predict the frequency of other missing data. There was a significant difference detected among classes of fragmentation (assuming a Poisson distribution for count data: Wald $\mathrm{X}^{2}=21.609, \mathrm{df}=2, \mathrm{P}<0.001$ ), but this was due to the large difference in number of missing populations between species that were not severely fragmented and those with missing information regarding total population fragmentation (post-hoc comparison, $\mathrm{df}=2, \mathrm{t}=12.075, \mathrm{P}=0.001)$ and not due to differences between fragmented and non-fragmented populations (Table 4). Species that had missing entries for fragmentation had $2.296 \pm 0.4891$ missing parameters on average while species that reported sever fragmentation only had $0.855 \pm 0.1791$ missing parameters.

Species with populations of uncertain status did not differ from populations that did not report populations of uncertain status for any of the parameters studied. Fragmentation was marginally significant $\left(\right.$ Wald $\left.X^{2}=5.004, \mathrm{df}=2, \mathrm{P}=0.082\right)$ due to the large difference between species reporting severe fragmentation and those with missing data (post-hoc comparison, $\mathrm{df}=3, \mathrm{t}=3.910, \mathrm{P}=0.061$ ). Species with more populations of uncertain status tended to occupy a smaller proportion of their range (AO/EO) $(\beta=-$ $0.025, \mathrm{~F}=4.980 \mathrm{df}=1, \mathrm{P}=0.025)($ see Table 5$)$ 
Table 4. Results of ANCOVA testing whether missing data can be predicted by traits related to species ephemerality, susceptibility to demographic stochasticity, and susceptibility to geographical isolation, using Poisson distribution and SPSS Statistics 21 (1989, 2012; SPSS Inc., Chicago Illinois USA). The number of missing data points was the response variable and a number of report parameters the independent variables: life span, tissue type, fragmentation, as fixed factors and the proportion of the range occupied $(\mathrm{AO} / \mathrm{EO})$ as covariate. Information that was originally missing from the status reports was added from USDA PLANTS database (USDA, 2014).

\begin{tabular}{|c|c|c|c|c|}
\hline & Wald $X^{2}$ & df & $\mathbf{P}$ & \\
\hline Intercept & 2.876 & 1 & 0.090 & \\
\hline Life Span & 0.713 & 1 & 0.398 & \\
\hline Tissue Type & 0.700 & 1 & 0.403 & \\
\hline Fragmentation & 21.609 & 2 & 0.000 & \\
\hline \multirow[t]{4}{*}{ AO/EO } & 0.775 & 1 & 0.379 & \\
\hline & $\begin{array}{l}\text { Fragmentation } \\
\text { Status } \\
\text { No Data on } \\
\text { Fragmentation } \\
\text { Status }\end{array}$ & Mean & 0.4891 & $\begin{array}{c}\text { pairwise } \\
\text { comparison } \\
\text { Sig. }\end{array}$ \\
\hline & $\begin{array}{l}\text { Not } \\
\text { fragmented }\end{array}$ & 1.063 & 0.2611 & \} 0.001 \\
\hline & $\begin{array}{l}\text { Severely } \\
\text { fragmented }\end{array}$ & 0.855 & 0.1791 & \} 0.411 \\
\hline
\end{tabular}


Table 5. Results of ANCOVA testing whether populations of uncertain status can be predicted by traits related to species ephemerality, susceptibility to demographic stochasticity, and susceptibility to geographical isolation, using Poisson distribution and SPSS Statistics 21 (1989, 2012; SPSS Inc., Chicago Illinois USA). The number of populations with uncertain status was the response variable and a number of report parameters the independent variables: life span, tissue type, fragmentation, as fixed factors and the proportion of the range occupied (AO/EO) as covariate. Information that was originally missing from the status reports was added from USDA PLANTS database (USDA, 2014).

\begin{tabular}{lrrr} 
& Wald X2 & df & \multicolumn{1}{c}{ Sig. } \\
Intercept & 8.095 & 1 & 0.004 \\
life span & 0.095 & 1 & 0.758 \\
tissue type & 0.527 & 1 & 0.468 \\
fragmentation & 5.004 & 2 & 0.082 \\
AO/EO & 5.205 & 1 & 0.023
\end{tabular}




\section{DISCUSSION}

\subsection{Discussion of Findings by Question}

\subsubsection{Question 1: Which Population Parameters Are Missing Needed Information?}

On average, species were missing data ("unknown”s or blank entries) for a total of $1.33 \pm 1.45$ out of 9 parameters given in the reports and analyzed in this study $(\mathrm{n}=$ 103 , median $=1, \min =0, \max =6$ ). This resulted in a total of 137 missing data points across all species and examined parameters. Most species were missing only one or two data points out of the nine chosen for this study, but of the data missing, most is attributable to missing abundance estimates (79 missing points out of 137 total $=58 \%$ ), including information on number of known populations, total number of individuals, and minimum and maximum number of individuals in a single population. The remainder consisted of missing geographical $(33 / 137=24 \%)$ and biological information $(25 / 137=$ $18 \%)$.

\subsubsection{Many Status Reports Are Missing Biological Information}

Twenty-five species (24\%) were missing biological information, in the form of either life history or tissue type. Tear et al. (1995) found distribution data was most commonly reported for American listed vertebrate species (88\%) in recovery plans while abundance data was available about half as often. This may reflect improved data availability in American reports or a bias towards estimates for animals. There is little literature available to compare vascular plant species. Biological information about species life history patterns is crucial to understanding population dynamics over time and therefore essential to population management (Clark et al. 2002; Boersma, 2001; 
Rohlf, 1991). This may pertain to either the types of ecological interactions species have with other organisms or with the environment, both of which alter the reproductive health, death rates, and seedling establishment.

\subsubsection{Many Status Reports Are Missing Single Population Abundance Estimates}

In addition to number of populations, which will be discussed later, reports were also often either reporting approximate values or leaving entries blank for other descriptive parameters. More than a third of reports did not include the minimum and maximum number of individuals in a single population, indicating missing single population estimates. Three of these species probably didn't have these parameters included because they only had one known population, negating the need to record two different abundance estimates, and five species probably did not record it because they have zero known populations and are presumed extirpated. The rest, however, essentially only offer presence/absence values at the population level, contrary to popular recommendation for quantitative abundance data (Justice Laws, 2002; Sleep and Trout, 2013; Ontario, 2007; IUCN, 2010). I calculated average population size for myself by dividing total number of individuals by number of known populations, an estimate that revealed sizes for 92 out of 103 species (89\%), but these estimates are approximate, evenly distributed by averaging, and not based on field observations and thus would not be used for management purposes. Estimating other parameters in this way is likely not possible as more field data is needed. Total number of individuals for the species was noted more often $(96 / 103$ species $=93 \%)$, but I am unclear about how this figure could have been estimated with much confidence considering how many single population 
estimates were missing. Perhaps single population estimates are simply not reported in the reports though they are collected and used to estimate total species abundance. In either case, it is unclear how many individuals make up populations of ar-risk plant species in Canada.

In total, there were seventy-nine missing abundance estimates in the form of either total number of individuals, minimum number of individuals in a population, or maximum number of individuals in a population. Thirty-eight and 37 species were missing single population abundance estimates in the form of min and max number of individuals, respectively. This is $37 \%$ of all 103 species I was able to collect information from and 22\% of all 172 listed species (extirpated, endangered, or threatened) in Canada. Gerber and Hatch (2002) found that population size was the most frequently used quantitative recovery criterion in American recovery plans, whereas I found total number of individuals was the parameter in Canadian reports that was missing the least. This lack of abundance measures for single populations is a problem, firstly, for assessing the overall health of species, as population size is important for assessing extirpation risk (Haines et al., 2013; Schemske et al. 1994; Boersma et al. 2001; Lodge et al., 2006). Secondly, abundance estimates are important for making regional goals for species protection. As populations may reside in areas of different environmental governance from one another, it is important to know where the most vulnerable populations are. Thirdly, monitoring species recovery requires tangible measures of change over time. Changes in abundance at the population level may signal population growth or decline as a result of regional influences. These need to be identified and understood to ensure species conservation. 


\subsubsection{Many Status Reports Are Missing Distribution Information}

Thirty-three species (32\% of all 103 species studied) were missing geographical information in the form of either extent of occurrence, area of occupancy, or degree of fragmentation. Spatial information, such as species ranges and total population fragmentation, is important for assessing health at both the population and species level and also for setting management goals for the data it lends to distribution. This includes data on the distance between populations and the distance between individuals. Furthermore, these parameters are recognized by COSEWIC as being necessary for informing status designation (Justice Laws, 2002).

\subsubsection{Question 2: What Proportion of Species Have At Least One Population of Uncertain Status/Existence? How Many Populations of Uncertain Status Do These Species Have On Average?}

\subsubsection{Many Status Reports Are Missing Presence/Absence Data for At Least One Population}

Many status reports either directly reported missing populations in their "number of uncertain populations" parameter or indirectly implied missing populations by giving the "number of known populations" in a range. To clarify, what the reports call uncertain populations and I call populations of uncertain status, refers to populations that were at one time known or suspected to exist but that have either not been located with recent surveys or not been surveyed at all. Of the 103 species I was able to find complete status reports for, twenty-one (20\%) had at least one or more populations of uncertain status, 
typically making up 25\% (median) to 39\% (average) of the total number of populations for the whole species in Canada. This means that, in 2013, 20\% of Canadian at risk species with status reports only had reliable presence/absence data for a maximum of three quarters of their populations. Therefore, $52 \%$ of all listed Canadian at-risk plant species do not have reliable population presence/absence data because they either do not have a status report $(60 / 172=40 \%)$ or they have too many missing populations $(21 / 172=$ $12 \%)$.

Populations may go missing between surveys for a couple reasons: the population may have died out, which is more likely to happen when the last survey abundance estimates for that population were very low; the population may have shrunken to a size that is no longer detectible by the survey technique being used; the population may have shifted boundaries if growth over time was directional; differences in survey technique between years as well as differences in investigator may result in different survey results, and finally, it is possible that the population has never been formally surveyed but instead only reported by casual naturalists (Barry and Welsh, 2001; Melville and Welsh, 2001; Rew et al., 2006). In any case, missing populations contribute a large degree of uncertainty to the overall understanding of the species' status in Canada and therefore drastically limit management attempts (Sleep and Trout, 2013; Rew et al., 2006). Little more than half of Canadian species not having reliable presence/absence data at the population level is concerning. Knowing the number of populations present in Canada, or present in local areas, for at-risk species is important for not only for having a general idea of true species presence and distribution but because the number of breeding populations may affect the long term health status of the species (Schemske et al., 1994; 
Engen et al., 2003; Vindenes et al., 2008). More populations may mean more individuals, a basic qualifier for reduced status. Presence data is especially important for assessing the likelihood of rescue effect occurring for the most threatened populations. Where one population is particularly threatened because of low number of individuals, the conservation prioritization for that species could change if a missing population near it was confirmed, or similarly if a new nearby population was found, as more populations enhances the rescue effect (McArthur and Wilson, 1967; Richter-Dyn and Goel, 1972). Obtaining absence data is difficult, as not finding a population does not necessarily mean it was not truly there (Engler, 2004), but increased confidence in presence data may suffice in place of true absences and should be a priority for COSEWIC's future efforts. This may require more field investigation for species where presence data is particularly incomplete.

\subsubsection{Summary of Missing Information}

Not including the 29 Special Concern species I did not search for, only 103 species out of the possible 172 listed had available status reports in 2013. This means that only approximately $60 \%$ of the most at-risk Canadian vascular plant species currently have potentially reliable status reports. COSEWIC did often provide at least an executive summary when status reports were missing, but these were not necessarily comprehensive enough for extracting population data. In addition, many of the reports that were available were often lacking in presence/absence and abundance data as well as biological and geographical species-specific information. These are described below. To compare to other studies, in 2005, Venter et al. (2006) found there were 151 vascular 
plant species listed by COSEWIC. In extracting information on threats facing listed species, Venter et al. used COSEWIC status reports, executive summaries, and Canadian Wildlife Service data to inform their study, acknowledging that the data sources COSEWIC uses for compiling species-specific information does not often come from experimental or quantitative sources. They did not comment on how many status reports they were able to find or use. Neel, et al. (2012), examining all species types under the American Endangered Species Act, were able to extract information from 1173 recovery plans out of 1320 listed species (89\%), the equivalent informative document to Canadian Status Reports. This is much larger than the proportion of species I was able to find information for in Canada.

$52 \%$ of all listed Canadian at-risk plant species do not have reliable population presence/absence data because they either do not have a status report $(60 / 172=40 \%)$ or they have too many missing populations $(21 / 172=12 \%$, of 103 species studied $=20 \%)$. Seventy-seven percent of all 103 species I was able to collect information from (extirpated, endangered, or threatened) in Canada were missing abundance estimates in the form of either total number of individuals, minimum number of individuals in a population, or maximum number of individuals in a population. Thirty-three species (32\% of all 103 species studied) were missing geographical information in the form of either extent of occurrence, area of occupancy, or degree of fragmentation, and twentyfive species (24\%) were missing biological information, in the form of either life history or tissue type. 


\subsubsection{Question 3: Are Some Species More Likely to Have Missing Information?}

If survey difficulties are one of the main reasons for missing information in species reports, as suggested by literature (Barry and Welsh, 2001; Melville and Welsh, 2001; Rew et al., 2006; Sleep and Trout, 2013; Buckland et al., 2007), then it is important to identify situations where surveys are likely to yield incomplete data. These may include situations where the traits of particular species make new populations difficult to locate or known populations difficult to extract data from. I have suggested 4 possible situations in Appendix A-3 that might reduce field data quality despite not finding statistical justification for them, as described below. Here I discuss the results of my attempt at relating species-specific traits to the number of missing populations reported by the status report.

\subsubsection{Are Particular Species More Likely to Report Missing Data Points in Report Parameters For Some Common Reason?}

My ANCOVA did not reveal significant differences in total number of missing data points between species. There was a significant difference detected among classes of fragmentation, but this was due to the large difference in number of missing populations between species that were not severely fragmented and those with missing information regarding total population fragmentation and not due to differences between nonfragmented and fragmented populations. This means that species with missing data, at least in terms of fragmentation, may be more likely to have missing data in other areas as well. It does not mean, contrary to my assumptions, that a higher degree of population fragmentation makes species more likely to have missing data. 


\subsubsection{Are Particular Species More Likely to Report Missing Populations For Some Common Reason?}

Ephemerality of above-ground biomass may affect the likelihood of encountering an individual at ground level due to differences in time plants exist in various forms. Annual and herbaceous species may be more difficult to find on average because they tend not to persist over winter and may only exist as seed bank for some years across environmental gradients. Woody species are more likely to survive or at least persist in a dead but identifiable form through small fires and floods but are more likely to disappear during extensive flooding (Bellingham and Sparrow, 2000; Marba et al., 2007). The vast majority of Canadian listed species are herbaceous (77\%) with more than a quarter of all species being both herbaceous and annual. Statistical analysis by means of a contingency table revealed no significant differences between species that reported populations of uncertain status and those that did not with respect to ephemerality of the species. Life history and tissue type, according to my findings, have no effect on whether a population is likely or unlikely to report a missing population. This is contrary however to how the IUCN and Sleep and Trout (2013) understand surveying difficulties. Both point out how accurate data may be difficult to obtain from short-lived species. Species with short life spans fluctuate significantly in population parameters over time, a characteristic that is normally predictive of higher extinction risk but that is natural for short-live species (IUCN 2010). These species may be more likely to report missing populations, simply because they have shifted their boundaries or died out faster than longer-lived species. It is more likely that the species under study here are so varied both in life history traits and tissue type, as well as number of other characteristics, that I was unable to discern a 
difference between them looking at individual traits at a time. Being herbaceous may render a species more likely to disappear over the winter, thereby becoming harder to survey for, but only if surveys are conducted during the winter. Woody plants may persist longer after fires, but this is only relevant to surveys in areas prone to wildfires. Similarly, populations of herbaceous or annual plants may be prone to shorter life cycles than woody plants or even perennial herbs, but they may also be faster to regenerate after death, or happen to be more genetically diverse, or have ample resources in their landscape placement, or any other number of factors that might give them an advantage despite their possibly disadvantageous ephemerality. It is obvious that many more factors are at work in determining the ease with which a population of plants might be surveyed.

The amount of information missing in Canadian status reports contradicts acknowledgements by SARA and literature over the importance of biological information in assessing species status (Sleep and Trout, 2013; IUCN, 2010). Twenty-five species (24\%) were missing either life history or tissue type information. I would suggest, despite finding a relationship between these species-specific traits and surveying difficulty, that such biological knowledge needs to be vastly improved in COSEWIC status reports in part for the possible relationships I have presented here and in part because of wide agreement in literature (Clark et al. 2002; Boersma, 2001; Rohlf, 1991). Biological information is already accepted as being widely important for understanding population dynamics, and therefore integral to assessing extinction risk. I am suggesting that it is additionally important for prioritizing species for further investigation, as it may hint at the likelihood of obtaining high quality data from the field. Life history may affect surveying difficulty in a number of ways depending on the species of interest and the 
nature of the population location. Tissue type as well may alter survey effectiveness depending on the species and time the investigation takes place. Seed banks present a unique problem to comprehensive plant surveys because clearing events such fire and flood are likely to open space for the dormant seeds. COSEWIC did not have thorough biological information on individual species to estimate likely seed bank persistence times, and therefore was not analyzed with the other parameters in this study. However, seed bank residency time should be specified more often in status reports for the information it may lend to surveying ease, and therefore also to the quality of retrieved field data. My results are novel here in two ways. Firstly, I have revealed a large degree of missing data associated with biological information in Canadian status reports. Secondly, I have for the first time revealed possible predictors of data reliability when collecting information for at-risk plant species, though I did not find statistical significance. Based on sound theory, it is reasonable to assume ephemerality would pose surveying challenges were all other factors held constant. I would suggest first, that further collection of species biological knowledge be undertaken to improve the information used to assist in status designation and, second, that species with the traits I have outlined here be reconsidered for further survey work, as the data coming from these populations may be less reliable than that of other species.

Susceptibility to stochasticity may affect the likelihood of collecting representative data from plant populations because it affects the size and longevity of populations. In my findings, population size was highly skewed towards species with lower average abundances, meaning that most Canadian-listed species exist in populations of few individuals. This is not surprising for species at risk. Small population 
size combined with the few number of populations there are to begin with may make most listed species difficult to locate using traditional ground survey techniques (Barry and Welsh, 2001; Melville and Welsh, 2001; Rew et al., 2006). Hence, assuming these trends are true for all populations of the species, locating new populations with traditional survey techniques will be very difficult for most listed species. Small populations are also the ones that tend to die out as a result of stochastic effects, meaning known populations may be more likely to disappear from record between survey dates (Kokko and Ebenhard, 1996; Schemske et al., 1994; Engen et al., 2003; Vindenes et al., 2008). Even so, there were no significant differences between species reporting populations of uncertain status and those that did not with respect to abundance. This may be because of faulty logic in the creation of my parameter for population size. Average population size is not given in status reports and I did find that the minimum and maximum number of individuals for a single population was not reported for more than a third of listed species, indicating that abundance estimates for many populations are not known. It is possible that my averaged parameter, using the given parameters of total number of mature individuals and area of occupancy, has made species appear more similar to each other in size than they actually are. At the least, I think these findings identify a significant weakness in the parameters given by status reports, in the reporting of about two thirds of the single-population abundance estimates for listed species. Quantitative abundance estimates are cited as being needed for extinction assessment by both the IUCN and Canada (IUCN, 2010; Justice Laws, 2002), yet, in 2013, Canadian species were underrepresented in both available status reports ( $40 \%$ of all listed not available) and single population abundance estimates (38\% of 103 studied not available). This means that only 64 species out of all 
listed 172 at-risk species in Canada (37\%) had abundance estimates at the populationlevel. Though most of this is due to status reports being unavailable, there is an obvious and large knowledge gap in how many individuals make up the known populations of atrisk plant species in Canada. This needs much improvement, firstly, to improve the availability of information that aids in species assessment according to cited need in Canada (Jusitce Laws, 2002; Ontario, 2007), and secondly, to better inform further search effort for small populations that may be misrepresented in current survey work.

Geographical isolation may affect the reliability of field data for plant populations because it affects the size of the search area and individual population persistence over time. Average geographical population size was small for most species, indicating that individuals of Canadian listed species tend to be clumped together. The proportion of range a species actually occupies in space was also skewed towards smaller values, indicating that the geographical area most species take up is significantly smaller than their respective ranges. For known existing populations, having a large range and small area of reported occurrence may mean there is potential for highly dispersed species to move undetected outside their recorded population boundaries. New populations could also exist across a vast expanse of the remaining range, assuming the necessary conditions. Because the remaining range is so large, the likelihood of finding new populations may be much reduced compared with species that tend to grow only in one area of the country. However, there were no significant differences between species reporting populations of uncertain status and those that did not with respect to this parameter, likely because most listed species do not exist in populations with highly dispersed individuals but rather are clumped in one or a few locations. Populations that 
are tightly clumped as opposed to spread out over a large area may be both easier to find and assess for population parameters such as abundance and geographic size.

Twice as many species were reported as having fragmented populations compared with those that were reported as not fragmented. Together with other findings in this study, this means that listed species tend to exist in small, isolated clumps with few individuals in each group. Unrecorded populations such as these may be easily missed by surveys. Furthermore, known populations may be more likely to disappear between surveys due to the compounding consequences of isolation and small population size (Henle et al., 2004) already outlined in this paper. Still, there were no significant differences between species reporting uncertain populations and those that did not, with respect to total population fragmentation, likely for the reasons already explained. Fragmentation was marginally significant due to the large difference between species reporting severe fragmentation and those with missing data. The proportion of the range occupied (AO/EO) was also marginally significant and negatively sloped, indicating that smaller AO/EOs may be related to increased number of missing populations. This would make sense, as fragmentation and isolation may impair the ability to detect populations. Habitat fragmentation is generally expected to be detrimental to the survival of small populations (Lienert, 2004; Baur et al., 1995; Boswell et al., 1998). Across groups of species though, it may not be reasonable to assume this effect works in the same way. Monocots, graminoids, clonal, abiotically pollinated, and self compatible species are underrepresented in studied on habitat fragmentation (Hienken and Weber, 2013) and our study system may be too broad across a taxonomical range to see differences. Furthermore, we may be seeing compound effects across the parameters examined in this 
study. Like the other parameters however, a large amount of information about the distribution of species was missing from Canadian status reports. Thirty-three species (32\% of all 103 species studied) were missing geographical information in the form of either extent of occurrence, area of occupancy, or degree of fragmentation. This information is necessary for accurately informing status assessment according to SARA and the IUCN (Justice Laws, 2002; IUCN, 2010). I am suggesting, despite not finding a significant relationship, that it may also be important for targeting further investigation into species with highly fragmented populations, as they may not reveal confident population-level data as accurately as other species.

\subsection{Implications for Managing Species At Risk}

Threatened and endangered plant species are rare because they occur in very few, small, or highly dispersed populations continually affected by anthropogenic and natural stressors (Sleep and Trout, 2013; Rabinowitz, 1981; Rabinowitz et al., 1986). Quantitative data on population characteristics do not exist for many of the species listed in the US Endangered Species Act, likely due to the technical and financial difficulties associated with obtaining accurate distribution and abundance data for species with these characteristics (Sleep and Trout, 2013; Rew et al., 2006). Yet, the American and Canadian acts both heavily stress the importance of quantitative data for informing recovery strategies (Sleep and Trout, 2013; Justice Laws, 2002; Rew et al., 2006; Neel et al., 2012; Neel et al., 2013). In fact, species listed under the American act have been shown to be more likely to recover when their recovery plans emphasize quantitative population parameters (Haines et al,. 2013). More often though, reports for American 
species do not include data required by the recovery objectives or inventory goals, most of which are quantitative (Neel et al., 2012; Stohlgren et al., 1995). Abundance data specifically are often left out or reported as educated guesses (Tear et al., 1995). We know that conservation efforts in the USA are more successful when status reports are made but there is wide consensus that American reports require much greater emphasis on species biology for setting and assessing recovery criteria (Schultz and Gerber, 2002; Taylor et al., 2005). Thus, the American Endangered Species Act process that determines whether or not to list a species has been criticized for being too subjective (Ferraro et al., 2007; Robbins, 2009).

Two things are therefore needed for informing environmental management and policy decisions: highly representative landscape surveys and the reporting of error in imperfect data. This is particularly important for the management of threatened or endangered species (Neel and Che-Castaldo, 2013), species that are used as indicators of ecological performance (Mandelik et al., 2010), and invasive species (Verloove, 2010). Loss of biodiversity is one of the greatest threats to ecosystem functioning. The removal of one species can have profound effects on the ecology of others connected by competition dynamics and food web structure (Ferenc et al., 2006; Gustafsson and Bostrom, 2011). In Canada, there has been little review of the quality of plant population data. In order to manage the conservation and recovery of rare plants then, land managers and policy makers must firstly, know the current locations of important populations and, secondly, be able to accurately collect or estimate characteristics of these populations (such as abundance). If we are inaccurately estimating information about the locations and abundances of these populations, then it is possible that some rare species may be 
more or less rare than their current listing suggests and may therefore be incorrectly prioritized.

\subsection{Conclusion}

Before taking on this study, I had noticed that some, but not all, SARA-listed species seemed to be missing population presence/absence data as well as descriptive information for the populations that were present. I assumed that this missing information represented species that were more difficult to achieve representative data from, because of either biological or spatial constraints on the ability to survey populations. I therefore assumed that these species would have traits, whether they be biological, ecological, or geographical characteristics, in common that, if understood, may be used to better target and inform searches, and therefore improve the confidence of COSEWIC status designations. To investigate this I compared both the proportion of species reporting populations of uncertain status to those that did not and the degree of missing data among species, with respect to the species and population parameters given by the COSEWIC status reports. No significant differences were found in any parameter between species. This may indicate that all listed species are equally likely to report missing information. I think though that it is more likely I was unable to discern differences because the parameters themselves were too broad. Populations may differ in ephemerality, population size, and fragmentation for many reasons. Those reasons may in turn aid in maintaining the existence of the population. For example, the herbaceous species analyzed in this study may be more likely to report populations of uncertain status, but that effect may be masked by the fact that all of those species also happen to have large 
populations, or non-fragmented populations, or any other population character that may make them easier to locate and survey for. Looking at one parameter at a time, I could not separate species so that other parameters were not possibly influencing the ability of an investigator to collect complete or representative field data. Therefore, in this study I could not identify single species traits that significantly alter the likelihood of finding and properly surveying a population of that species. However, I do recommend traits in this thesis that, in certain combinations, may affect the quality of data being retrieved from field surveys (Appendix A-3).

Without accurate population-level data it is impossible to reliably assess the status of any species (Regan et al., 2006). Many types of population-level information are missing for Canadian species at-risk. Furthermore, it is nearly impossible to systematically improve the likelihood of obtaining complete and representative data (Foin et al., 1998) in surveys when dealing with a large study area, as conservation is inherently inefficient simply due to financial and logistical constraints (Miller et al., 1994). Prioritization must therefore occur in other ways (Norton, 1988). While there are a number of factors that should inform species prioritization, lack of reliable data makes biologically informed parameters difficult to set. Other investigators have made various suggestions for improving population-level data quality, including the use of diverse author groups in report writing and greater biological information (Gerber and Schultz, 2001), Sleep and Trout, 2013; IUCN, 2010; Clark et al. 2002; Boersma, 2001; Rohlf, 1991). At the applied level though, prioritization is likely to boil down to costeffectiveness (Arponen, 2012; Possingham et al., 2002). Determining the state of conservation funding for each species is nearly impossible as reports do not mention 
recovery feasibility from a financial perspective (Miller et al., 2002) and some stress the issue of allocating conservation dollars to highly threatened species without justification of likely improvement (Possingham et al., 2002).

Assessment of data quality though may aid in prioritizing species for conservation because it allows investigators to allocate a degree of confidence to particular species. Prioritizing conservation only for species that are confidently assessed as being at-risk may save time and financial resources. It is important therefore to identify species for which improved data availability and accuracy is most important. This should reduce spending and effort at ensuring data quality for all species. Species that are annual, herbaceous, take up a relatively small proportion of their range, have small average population sizes in number of individuals or geographical space, and that have a high degree of fragmentation both between individuals and between populations, may be at greater risk of reporting biased or incomplete survey data, all other factors held equal. Species with these traits, or combinations of traits, may therefore require further investigation into their true population parameters before they can be confidently assessed and given a formal status designation by COSEWIC. I have included a list of all species with their traits and report authors in Appendix A-1 and A-2. I would recommend that species with my predictor traits be prioritized for more intensive investigation into their population-level characteristics to ensure that surveying difficulty has not impaired the quality of the data retrieved from the field. I would also recommend that the species indicated by grey shading in Figure 2 be investigated with further survey work to obtain the quantitative information missing from reports presently that cannot be estimated. Furthermore, I would recommend that all investigations into species status make greater 
emphasis on collecting and reporting population level abundance estimates, as these seem to be largely missing from status reports currently and are integral to assessing population and species health as well as cost effectiveness of recovery.

\subsection{Limitations and Recommendations for Future Work}

There are a number of limitations to this study. Firstly, I have only analyzed the parameters given by the reports I had available. There is an abundance of information on species biology outside these sources that could better inform my predictions. I did not look at typical plant size or flower morphology here for example, which may affect the likelihood of an individual being discovered during a survey. I also did not look at any predator or human interactions that may have affected the longevity and therefore surveying difficulty of various species. There may be other traits that species reporting populations of uncertain status have in common that could help predict how difficult it will be to find and/or properly assess populations. However, quantitative information on populations is likely only available from government-regulated bodies. Perhaps a combination of species data from provincial and federal sources would have reduced the number of missing data points I found in my analysis of the SARA registry. There are many organizations in Canada, including the provincial species management bodies, that could contribute data to the status assessment process for at-risk species (NCASI, 2010), though it is unclear how many of these are consulted during species assessments due to time and resource constraints on COSEWIC investigators (Sleep and Trout, 2013). Improved data sharing in general would both improve the rigour of my analyses and the state of Canadian at-risk plant monitoring in general. I was able to quickly add additional 
biological information relating to life span and outer tissue type to my dataset when answering Question 3. Perhaps, with more effort, much of the information I found to be lacking could be filled in to form a more complete dataset for Canadian plant species, allowing for larger sample sizes in my analysis attempting to discern a relationship between traits and missing information. Collection of most quantitative parameters though may be limited by the availability of survey records and therefore may not be as easy to obtain without further survey work. There is also bias in the small sample size of the species reporting populations of uncertain status. For example, of the 21 species that reported populations of uncertain status, very few were woody or annual, limiting my ability to draw conclusions on my comparisons. This could be improved by including more species into the dataset.

I only looked at Canadian species in this study, which may display less diversity in form and function being located at a northern latitude. There is sampling bias present in my analyses. The final number of species studied (103) was not a large sample of subjects nor a large proportion of all potentially at-risk species, as my results show there are many species that simply do not have reports yet. Furthermore, Canadian species may be inherently more similar to each other than when comparing between species around the world or over a whole continent, and these similarities may have prevented me from seeing any difference in survey difficulty. There are also significantly fewer species listed in Canada than there are in the United States, limiting my sampling size. Expanding this analysis to look at American species, or even just including Canadian special concern species, may increase our chances of seeing significant differences in number of missing populations between species. A comparison to American data would be especially 
interesting because we could compare across management strategies in different conservation bodies.

There are also limitations associated with the use of meta-analyses. Like all metaanalyses (Gurevitch and Hedges, 1999), I was faced with two sources of error here. Firstly, the reports I used to collect this information from were written by different authors, compiled from different sources of data, and by different survey and estimation techniques. There is likely to be some discrepancy between reports solely based on these factors. Therefore, comparing across reports may not be justified for cases where authors and primary investigators have different backgrounds or experiences. Also, many of the reports taken from COSEWIC were published in different years. While each represented the most recent report for their species, comparing across different time scales may have produced unwanted differences in how information was collected or presented. Secondly, it is possible my own data collection techniques were flawed. Though I indicated what information was to be extracted and where from each report, the recording was done by volunteers and I cannot account for their quality, though they were randomly assigned to species. I also took a great deal of freedom in my standardization of reported data parameters. As outlined in the methods, for certain parameters I often had to take the maximum number from ranges or pull information for another parameter out of a related parameter. Any changes in the process by which I standardized my dataset may alter my results. Also, species with a larger number of missing entries for certain parameters were less likely to offer any resolution to my comparative analyses. Given the nature of my data, it may have been more appropriate to weight species reports by quality (either in date created, author, or amount of missing data), but this would have required more time 
that I had. However, this could be easily done in the future to see whether the results reported in this study would change, given a new ranking of reports. I am also dealing with nonindependence of studies here, as some reports share an author. This may be another factor to consider if I pursue this idea further.

In the future, I would recommend a re-visitation of this data with abundance, distribution, and biological information added from either provincial or nongovernmental species monitoring sources. I would also be interested in comparing the results of this study to one examining the same trends for American species, particularly when species cross the border. To achieve better resolution in the relationships I have proposed here between species-specific traits and surveying difficulty, I think it would be useful to add extra parameters describing population dynamics in abundance, distribution, and biology. The few I analyzed were likely too interrelated to see differences in comparisons between species and increasing the number of traits analyzed may improve this. Together, these works might give us a better idea of the state of conservation registries in North American and may illustrate opportunities for improving data collection and management for at-risk plant species. 


\section{APPENDIX A: RAW DATA AND PREDICTOR TRAITS}

A-1: Raw data by species name and parameter value taken from the technical report or biology section of COSEWIC status reports for at-risk plant species. $N=103$. Proportion of range occupied was calculated as AO/EO*100, Average Population Size was calculated as total \# individuals / \# populations, and Average Geog. Population Size was calculated as AO / \# populations. (Report Authors are given in next table to meet formatting requirements)

\begin{tabular}{|c|c|c|c|c|c|c|c|c|c|c|c|c|c|}
\hline 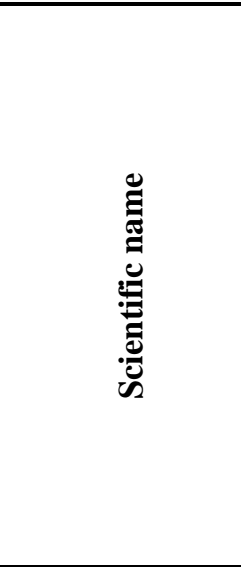 & 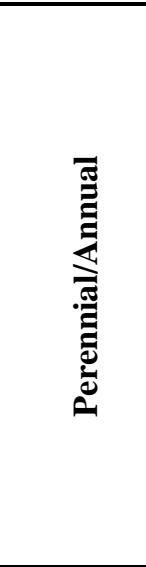 & & 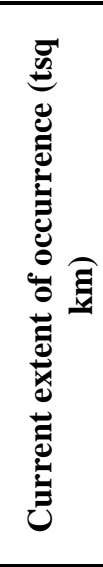 & 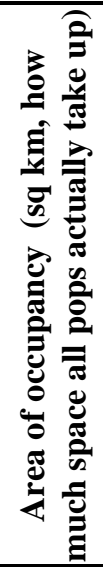 & 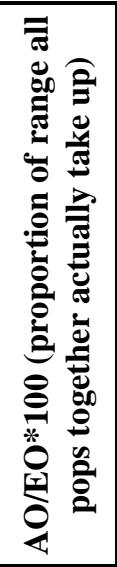 & 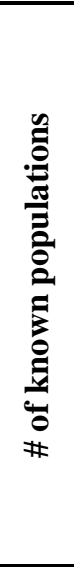 & 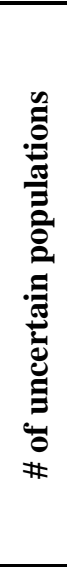 & 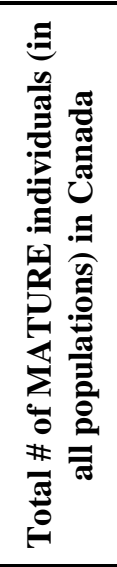 & 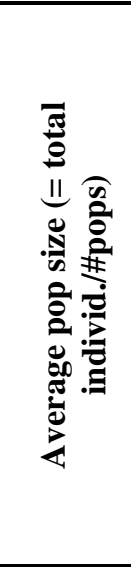 & 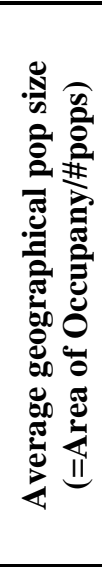 & 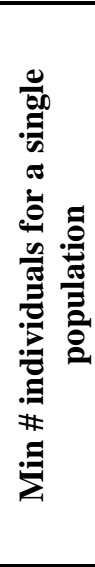 & 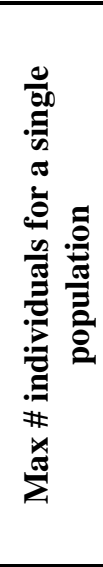 & 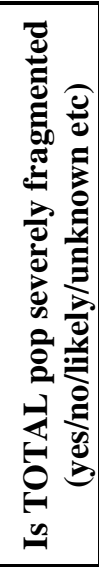 \\
\hline $\begin{array}{c}\text { Abronia } \\
\text { umbellata }\end{array}$ & Perennial & Herbaceous & 20 & 20 & 100 & 1 & & 5 & 5 & 20 & & & yes \\
\hline Actaea elata & Perennial & Herbaceous & 2075 & 0.11 & 0.01 & 8 & & 148 & 18.5 & 0.01 & 1 & 63 & yes \\
\hline $\begin{array}{c}\text { Adiantum } \\
\text { capillus-veneris }\end{array}$ & Perennial & Herbaceous & & & & 4 & 1 & 1863 & 465.75 & & 183 & 1300 & \\
\hline Agalinis aspera & Annual & Herbaceous & 3725 & 5 & 0.13 & 11 & & 250 & 22.73 & 0.45 & & & yes \\
\hline
\end{tabular}




\begin{tabular}{|c|c|c|c|c|c|c|c|c|c|c|c|c|c|}
\hline $\begin{array}{c}\text { Agalinis } \\
\text { skinneriana }\end{array}$ & Annual & Herbaceous & 70 & 20 & 28.57 & 2 & & 23000 & 11500 & 10 & 6000 & 17000 & no \\
\hline $\begin{array}{c}\text { Ammannia } \\
\text { robusta }\end{array}$ & Annual & Herbaceous & 50 & 0.01 & 0.02 & 3 & & 150000 & 50000 & 0 & 30 & 150000 & yes \\
\hline $\begin{array}{c}\text { Antennaria } \\
\text { Flagellaris }\end{array}$ & Perennial & Herbaceous & 4.8 & 0.0022 & 0.05 & 3 & & 1400000 & 466666.67 & 0 & 400 & 14000000 & no \\
\hline Azolla mexicana & Annual & Herbaceous & 5400 & 11 & 0.2 & 8 & & 10000000 & 1250000 & 1.38 & & & no \\
\hline $\begin{array}{c}\text { Balsamorhiza } \\
\text { deltoidea }\end{array}$ & Perennial & Woody & 1200 & 8 & 0.67 & 8 & & & & 1 & & & no \\
\hline $\begin{array}{c}\text { Bartonia } \\
\text { paniculata ssp. } \\
\text { paniculata }\end{array}$ & Annual & & 400 & 1 & 0.25 & 6 & & 1000 & 166.67 & 0.17 & & & \\
\hline Betula lenta & Perennial & Woody & 0.75 & 0.75 & 100 & 1 & & 14 & 14 & 0.75 & 14 & 14 & yes \\
\hline $\begin{array}{c}\text { Bouteloua } \\
\text { dactyloides }\end{array}$ & Perennial & Herbaceous & 2383 & 172 & 7.22 & 10 & 2 & 10000 & & & & & no \\
\hline $\begin{array}{l}\text { Buchnera } \\
\text { americana }\end{array}$ & Perennial & & 28 & 1.22 & 4.36 & 3 & & 488 & 162.67 & 0.41 & & 1940 & no \\
\hline $\begin{array}{c}\text { Calochortus } \\
\text { lyallii }\end{array}$ & Perennial & & 150 & 0.041 & 0.03 & 3 & & & & 0.01 & 40 & 400000 & yes \\
\hline $\begin{array}{l}\text { Camassia } \\
\text { scilloides }\end{array}$ & Perennial & Herbaceous & 4.5 & 1.1 & 24.44 & 6 & & 21200 & 3533.33 & 0.18 & 865 & 5680 & \\
\hline $\begin{array}{c}\text { Camissonia } \\
\text { contorta }\end{array}$ & Annual & Herbaceous & 750 & 1 & 0.13 & 7 & & 4500 & 642.86 & 0.14 & 20 & 1000 & yes \\
\hline $\begin{array}{c}\text { Carex } \\
\text { juniperorum }\end{array}$ & Perennial & & 3 & 1 & 33.33 & 4 & & 7000 & 1750 & 0.25 & 1000 & 5000 & yes \\
\hline
\end{tabular}




\begin{tabular}{|c|c|c|c|c|c|c|c|c|c|c|c|c|c|}
\hline $\begin{array}{c}\text { Carex } \\
\text { lupuliformis }\end{array}$ & Perennial & Herbaceous & 20280 & 40 & 0.2 & 12 & 1 & 166 & 13.83 & 3.33 & & & yes \\
\hline Carex sabulosa & & & 200 & 0.74 & 0.37 & 5 & & 5000000 & 1000000 & 0.15 & 38000 & 4000000 & no \\
\hline $\begin{array}{c}\text { Carex } \\
\text { tumulicola }\end{array}$ & Perennial & Herbaceous & 1700 & 10 & 0.59 & 10 & & 1445 & 144.5 & 1 & 1 & 500 & yes \\
\hline $\begin{array}{c}\text { Castanea } \\
\text { dentata }\end{array}$ & perennial & Woody & 11000 & 12 & 0.11 & 120 & & 150 & 1.25 & 0.1 & & & yes \\
\hline $\begin{array}{l}\text { Castilleja } \\
\text { levisecta }\end{array}$ & Perennial & Herbaceous & 100 & 4 & 4 & 2 & & 3400 & 1700 & 2 & 169 & 3192 & \\
\hline $\begin{array}{c}\text { Castilleja } \\
\text { rupicola }\end{array}$ & & Herbaceous & 1000 & 1 & 0.1 & 3 & 9 & 500 & 166.67 & 0.33 & 1 & 3 & yes \\
\hline $\begin{array}{l}\text { Castilleja } \\
\text { victoriae }\end{array}$ & Annual & Herbaceous & 9 & & & 3 & 1 & 8000 & 2666.67 & & 31 & 8000 & no \\
\hline Celtis tenuifolia & Perennial & Woody & 5000 & 20 & 0.4 & 6 & & 893 & 148.83 & 3.33 & 2 & 724 & yes \\
\hline $\begin{array}{c}\text { Centaurium } \\
\text { muehlenbergii }\end{array}$ & Annual & Herbaceous & 160 & 20 & 12.5 & 3 & & 1000 & 333.33 & 6.67 & & & yes \\
\hline $\begin{array}{c}\text { Chenopodium } \\
\text { subglabrum }\end{array}$ & Annual & Herbaceous & 82000 & 23 & 0.03 & 26 & 10 & 10000 & 384.62 & 0.88 & & & yes \\
\hline Cirsium hillii & Perennial & Herbaceous & 3000 & 30 & 1 & 64 & & 500 & 7.81 & 0.47 & & & no \\
\hline Cirsium pitcheri & Perennial & Herbaceous & 43438 & 136 & 0.31 & 30 & & 50435 & 1681.17 & 4.53 & & & \\
\hline Collomia tenella & Annual & Herbaceous & 0.056 & 0.056 & 100 & 1 & & 127 & 127 & 0.06 & & & yes \\
\hline Cornus florida & Perennial & Woody & 22500 & 150 & 0.67 & 154 & & 1300 & 8.44 & 0.97 & & & \\
\hline
\end{tabular}




\begin{tabular}{|c|c|c|c|c|c|c|c|c|c|c|c|c|c|}
\hline $\begin{array}{c}\text { Cryptantha } \\
\text { minima }\end{array}$ & Annual & Herbaceous & 15726 & 284 & 1.81 & 25 & & & & 11.36 & & & no \\
\hline Dalea villosa & Perennial & Herbaceous & 65973 & 344 & 0.52 & 25 & 4 & 145000 & 5800 & 13.76 & 2000 & 110000 & no \\
\hline $\begin{array}{c}\text { Drosera } \\
\text { filiformis }\end{array}$ & Perennial & Herbaceous & 77 & 11.5 & 14.94 & 5 & & 10000 & 2000 & 2.3 & & & yes \\
\hline $\begin{array}{c}\text { Eleocharis } \\
\text { geniculata } \\
\text { (great lake } \\
\text { plains) }\end{array}$ & Annual & Herbaceous & 7.7 & 5 & 64.94 & 3 & & 2500 & 833.33 & 1.67 & 300 & 2000 & \\
\hline $\begin{array}{c}\text { Enemion } \\
\text { biternatum }\end{array}$ & Perennial & Herbaceous & 1000 & 20 & 2 & 6 & & 1000000 & 166666.67 & 3.33 & 100 & 700000 & yes \\
\hline $\begin{array}{c}\text { Epilobium } \\
\text { torreyi }\end{array}$ & Annual & Herbaceous & & & & 0 & 2 & 0 & 0 & 0 & & & no \\
\hline $\begin{array}{c}\text { Eurybia } \\
\text { divaricata } \\
\end{array}$ & Perennial & Herbaceous & 1500 & 50 & 3.33 & 25 & & 9000 & & & 165 & 3800 & yes \\
\hline $\begin{array}{c}\text { Frasera } \\
\text { caroliniensis }\end{array}$ & Perennial & & 2000 & 1 & 0.05 & 12 & 1 & 4200 & 350 & 0.08 & & & yes \\
\hline Gentiana alba & Perennial & Herbaceous & 4.1 & 4.1 & 100 & 1 & & 42 & 42 & 4.1 & & & \\
\hline Geum peckii & & & 17 & 8 & 47.06 & 3 & & 9000 & 3000 & 2.67 & 500 & 8500 & no \\
\hline $\begin{array}{c}\text { Hymenoxys } \\
\text { herbacea }\end{array}$ & Perennial & & 75246 & 14 & 0.02 & 39 & & 6800000 & 174358.97 & 0.36 & & & yes \\
\hline $\begin{array}{c}\text { Isoetes } \\
\text { bolanderi }\end{array}$ & Perennial & Herbaceous & 0.02 & 0.02 & 100 & 1 & & 12000000 & 12000000 & 0.02 & & & yes \\
\hline $\begin{array}{c}\text { Isoetes } \\
\text { engelmannii }\end{array}$ & & & 15 & 0.1 & 0.67 & 4 & & 2000 & 500 & 0.03 & 50 & 300 & \\
\hline $\begin{array}{c}\text { Isotria } \\
\text { medeoloides }\end{array}$ & & & & & & 0 & 1 & 0 & 0 & 0 & & & no \\
\hline
\end{tabular}




\begin{tabular}{|c|c|c|c|c|c|c|c|c|c|c|c|c|c|}
\hline Juncus kelloggii & Annual & Herbaceous & 0.025 & 0.025 & 100 & 1 & & 600 & 600 & 0.03 & 3 & 6 & no \\
\hline Liatris spicata & Perennial & Herbaceous & 8800 & 172 & 1.95 & 10 & & 70000 & 7000 & 17.2 & 1 & 120000 & no \\
\hline Liparis liliifolia & Perennial & Herbaceous & 41200 & 75 & 0.18 & 10 & & 360 & 36 & 7.5 & 1 & 33 & no \\
\hline $\begin{array}{l}\text { Lipocarpha } \\
\text { micrantha }\end{array}$ & Annual & Herbaceous & 20 & 1 & 5 & 3 & & 50000 & 16666.67 & 0.33 & 70 & 50000 & yes \\
\hline $\begin{array}{c}\text { Lomantium } \\
\text { grayi }\end{array}$ & & & 50 & 2 & 4 & 2 & & 1300 & 650 & 1 & 240 & 1650 & \\
\hline Lophiola aurea & Perennial & Herbaceous & 3330 & 104 & 3.12 & 6 & 1 & 300000 & 50000 & 17.33 & 35 & 100000 & \\
\hline $\begin{array}{c}\text { Lotus } \\
\text { formosissimus }\end{array}$ & Perennial & Herbaceous & 24 & 4 & 16.67 & 5 & & 968 & 193.6 & 0.8 & 3 & 600 & no \\
\hline Lotus pinnatus & Perennial & Herbaceous & 100 & 0.0006 & 0 & 7 & & 2000 & 285.71 & 0 & 10 & 1500 & yes \\
\hline $\begin{array}{c}\text { Lupinus } \\
\text { densiflorus }\end{array}$ & Annual & Herbaceous & 2 & 0.0012 & 0.06 & 3 & & 2000 & 666.67 & 0 & 227 & 1045 & yes \\
\hline Lupinus lepidus & Perennial & Herbaceous & 12 & 5.5 & 45.83 & 2 & 1 & 250 & 125 & 2.75 & 250 & 250 & yes \\
\hline $\begin{array}{l}\text { Lupinus } \\
\text { oreganus }\end{array}$ & Perennial & Herbaceous & & & & 0 & & & & 0 & & & \\
\hline lupinus rivularis & Perennial & Herbaceous & 70 & 0.5 & 0.71 & 6 & & 248 & 41.33 & 0.08 & & & yes \\
\hline $\begin{array}{l}\text { Magnolia } \\
\text { acuminata }\end{array}$ & Perennial & Woody & 557 & 23 & 4.13 & 16 & 2 & 200 & 12.5 & 1.44 & 1 & 43 & yes \\
\hline $\begin{array}{c}\text { Meconella } \\
\text { oregana }\end{array}$ & Annual & Herbaceous & 2500 & 100 & 4 & 5 & & 3500 & 700 & 20 & 52 & 1274 & yes \\
\hline $\begin{array}{c}\text { Microseris } \\
\text { bigelovii }\end{array}$ & Annual & Herbaceous & 20 & 0.01 & 0.05 & 6 & & 6500 & 1083.33 & 0 & 50 & 2500 & yes \\
\hline
\end{tabular}




\begin{tabular}{|c|c|c|c|c|c|c|c|c|c|c|c|c|c|}
\hline $\begin{array}{c}\text { Minuartia } \\
\text { pusilla }\end{array}$ & Annual & Herbaceous & 0.01 & 0.01 & 100 & 1 & & 9 & 9 & 0.01 & 9 & 9 & yes \\
\hline $\begin{array}{c}\text { Orthocarpus } \\
\text { barbatus }\end{array}$ & Annual & Herbaceous & 45 & 1 & 2.22 & 3 & 1 & 12500 & 4166.67 & 0.33 & 367 & 8485 & yes \\
\hline $\begin{array}{c}\text { Orthocarpus } \\
\text { bracteosus }\end{array}$ & Annual & Herbaceous & 1 & 1 & 100 & 1 & & 300 & 300 & 1 & 300 & 300 & yes \\
\hline $\begin{array}{c}\text { Phacelia } \\
\text { ramosissima }\end{array}$ & Perennial & & 1 & 1 & 100 & 2 & 1 & 700 & 350 & 0.5 & 6 & 700 & no \\
\hline Phlox speciosa & Perennial & Herbaceous & 57 & 1.4 & 2.46 & 8 & 1 & 7000 & 875 & 0.18 & 5 & 2400 & \\
\hline $\begin{array}{c}\text { Plagiobothrys } \\
\text { figuratus }\end{array}$ & Annual & Herbaceous & & & & 0 & 1 & 0 & 0 & 0 & & & \\
\hline $\begin{array}{c}\text { Plagiobothrys } \\
\text { tenellus }\end{array}$ & Annual & Herbaceous & 300 & 0.35 & 0.12 & 7 & & 800 & 114.29 & 0.05 & 0 & 800 & \\
\hline $\begin{array}{c}\text { Plantago } \\
\text { cordata }\end{array}$ & & & 1 & 1 & 100 & 2 & & 8149 & 4074.5 & 0.5 & 3200 & 5083 & yes \\
\hline $\begin{array}{l}\text { Platanthera } \\
\text { leucophaea }\end{array}$ & Perennial & Herbaceous & 20000 & 10 & 0.05 & 20 & & 1000 & 50 & 0.5 & & & yes \\
\hline $\begin{array}{c}\text { Polemonium } \\
\text { vanbruntiae }\end{array}$ & Perennial & Herbaceous & 644 & 0.05 & 0.01 & 11 & & 20000 & 1818.18 & 0 & 1 & 13000 & yes \\
\hline $\begin{array}{l}\text { Polygala } \\
\text { incarnata }\end{array}$ & Annual & Herbaceous & 52 & 8 & 15.38 & 4 & & 1800 & 450 & 2 & 0 & 1700 & no \\
\hline $\begin{array}{c}\text { Polystichum } \\
\text { lemmonii }\end{array}$ & Perennial & Herbaceous & 0.024 & 0.024 & 100 & 1 & & 853 & 853 & 0.02 & 853 & 853 & no \\
\hline
\end{tabular}




\begin{tabular}{|c|c|c|c|c|c|c|c|c|c|c|c|c|c|}
\hline $\begin{array}{l}\text { Polystichum } \\
\text { scopulinum }\end{array}$ & Perennial & Herbaceous & 0.48 & 0.013 & 2.71 & 2 & 1 & 1000 & 500 & 0.01 & 215 & 412 & yes \\
\hline $\begin{array}{c}\text { Potamogeton } \\
\text { ogdenii }\end{array}$ & Perennial & Herbaceous & & & & 0 & 3 & & & 0 & & & no \\
\hline $\begin{array}{l}\text { Psilocarphus } \\
\text { brevissimus }\end{array}$ & Annual & Herbaceous & 2 & 0.001 & 0.05 & 3 & & & & 0 & 30 & 2000000 & yes \\
\hline Ptelea trifoliata & Perennial & & 117 & 7.5 & 6.41 & 34 & & 1025 & 30.15 & 0.22 & 1 & 350 & yes \\
\hline $\begin{array}{l}\text { Ranunculus } \\
\text { alismifolius }\end{array}$ & Perennial & Herbaceous & 500 & 8 & 1.6 & 2 & & 306 & 153 & 4 & 121 & 185 & yes \\
\hline $\begin{array}{l}\text { Ranunculus } \\
\text { Californicus }\end{array}$ & & Herbaceous & 20 & 8 & 40 & 5 & 1 & 3515 & 703 & 1.6 & 27 & 2700 & \\
\hline $\begin{array}{c}\text { Salix } \\
\text { chlorolepis }\end{array}$ & Perennial & Woody & 7.5 & 0.05 & 0.67 & 4 & & 300 & 75 & 0.01 & 300 & 300 & no \\
\hline $\begin{array}{c}\text { Sanicula } \\
\text { arctopoides }\end{array}$ & Perennial & Herbaceous & 4.3 & 3.6 & 83.72 & 5 & & 3650 & 730 & 0.72 & 52 & 6015 & yes \\
\hline $\begin{array}{c}\text { Sanicula } \\
\text { bipinnatifida }\end{array}$ & Perennial & Herbaceous & 676 & 12.5 & 1.85 & 26 & & 2000 & 76.92 & 0.48 & 1 & 1138 & \\
\hline $\begin{array}{c}\text { Sida } \\
\text { hermaphrodita }\end{array}$ & Perennial & Herbaceous & 35 & 12 & 34.29 & 2 & & 2510 & 1255 & 6 & & & no \\
\hline
\end{tabular}




\begin{tabular}{|c|c|c|c|c|c|c|c|c|c|c|c|c|}
\hline $\begin{array}{c}\text { Silene Scouler } \\
\text { ssp.grandis }\end{array}$ & Perennial & Herbaceous & 1 & 0.0158 & 1.58 & 2 & 350 & 175 & 0.01 & & & yes \\
\hline Silene spaldingii & Perennial & Herbaceous & 0.3 & 0.3 & 100 & 1 & 200 & 200 & 0.3 & 100 & 200 & yes \\
\hline $\begin{array}{c}\text { Smilax } \\
\text { rotundifolia } \\
\end{array}$ & Perennial & Herbaceous & 5000 & 50 & 1 & 50 & 10000 & 200 & 1 & & & \\
\hline $\begin{array}{c}\text { Stylohorun } \\
\text { diphyllum }\end{array}$ & Perennial & Herbaceous & 150 & 3 & 2 & 3 & 530 & 176.67 & 1 & 24 & 225 & yes \\
\hline $\begin{array}{l}\text { Symphyotrichum } \\
\text { frondosum }\end{array}$ & Annual & Herbaceous & 56 & 1 & 1.79 & 4 & 1000 & 250 & 0.25 & & & no \\
\hline $\begin{array}{c}\text { Symphyotrichum } \\
\text { praeltum }\end{array}$ & Perennial & Herbaceous & 1000 & 20 & 2 & 12 & 5000 & 416.67 & 1.67 & & & yes \\
\hline $\begin{array}{c}\text { Symphyotrichum } \\
\text { Laurentianum } \\
\end{array}$ & Annual & Herbaceous & 2000 & 5 & 0.25 & 28 & 12000000 & 428571.43 & 0.18 & & & \\
\hline $\begin{array}{c}\text { Symphyotrichum } \\
\text { prenanthoides }\end{array}$ & Perennial & Herbaceous & 1039 & 76 & 7.31 & 7 & 1000 & & & & & \\
\hline $\begin{array}{l}\text { Tephrosia } \\
\text { virginiana }\end{array}$ & Perennial & Herbaceous & 10 & 9 & 90 & 2 & 567 & 283.5 & 4.5 & 1 & 566 & no \\
\hline Tonella tonella & Annual & Herbaceous & 0.34 & 0.062 & 18.24 & 4 & 315 & 78.75 & 0.02 & 30 & 150 & yes \\
\hline $\begin{array}{c}\text { Tradescantia } \\
\text { occidentalis } \\
\end{array}$ & Perennial & Herbaceous & 500 & 10 & 2 & 5 & 22000 & 4400 & 2 & 100 & 9422 & yes \\
\hline
\end{tabular}




\begin{tabular}{|c|c|c|c|c|c|c|c|c|c|c|c|c|c|}
\hline Trillium flexipes & Perennial & Herbaceous & 7 & 2 & 28.57 & 2 & & 1500 & 750 & 1 & 453 & 1012 & no \\
\hline $\begin{array}{c}\text { Triphora } \\
\text { trianthophoros }\end{array}$ & Perennial & Herbaceous & 62 & 16 & 25.81 & 5 & & & & 3.2 & & & no \\
\hline $\begin{array}{c}\text { Triphysaria } \\
\text { versicolor }\end{array}$ & Annual & Herbaceous & 24 & 5 & 20.83 & 7 & & 104400 & 14914.29 & 0.71 & 49 & 89600 & no \\
\hline $\begin{array}{c}\text { Tripterocalyx } \\
\text { micranthus }\end{array}$ & Annual & Herbaceous & 9.7 & 1 & 10.31 & 2 & & 2 & 1 & 0.5 & 1 & 1 & yes \\
\hline $\begin{array}{l}\text { Triteleia } \\
\text { howellii }\end{array}$ & Perennial & Herbaceous & 50 & & & 9 & & 704 & 78.22 & & 1 & 450 & \\
\hline $\begin{array}{l}\text { Uropappus } \\
\text { lindleyi } \\
\end{array}$ & Annual & Herbaceous & 150 & 20 & 13.33 & 5 & & 2000 & 400 & 4 & 20 & 1190 & yes \\
\hline $\begin{array}{l}\text { Vaccinium } \\
\text { stamineum }\end{array}$ & & & 100 & 20 & 20 & 6 & & 250 & & & & & \\
\hline Viola pedata & Perennial & Herbaceous & 40 & 1.5 & 3.75 & 5 & & 5000 & 1000 & 0.3 & & & \\
\hline $\begin{array}{c}\text { Viola } \\
\text { praemorsa ssp. } \\
\text { praemorsa }\end{array}$ & Perennial & Herbaceous & 450 & 14 & 3.11 & 14 & & 49000 & 3500 & 1 & 3 & 20400 & yes \\
\hline Woodsia obtusa & Perennial & & 14,000 & 20 & 0.14 & 8 & 1 & 1400 & 175 & 2.5 & & 499 & yes \\
\hline
\end{tabular}


A-2: COSEWIC-listed plant species in 2013 by scientific name and status report author $(\mathrm{N}=103)$.

\begin{tabular}{|c|c|}
\hline Scientific Name & Report Author \\
\hline Abronia umbellata & $\begin{array}{l}\text { Douglas, G. (2004). COSEWIC status report on the pink } \\
\text { sand-verbena Abronia unbellata in Canada. Ottawa: } \\
\text { Committee on the Status of Endangered Wildlife in } \\
\text { Canada. }\end{array}$ \\
\hline Actaea elata & $\begin{array}{l}\text { COSEWIC. (2001). COSEWIC assessment and status } \\
\text { report on the tall bugbane Cimicifuga elata in Canada. } \\
\text { Ottawa: Committee on the Status of Endangered Wildlife } \\
\text { in Canada. }\end{array}$ \\
\hline Adiantum capillus-veneris & $\begin{array}{l}\text { Miller, M. T. (2011). COSEWIC. 2011. COSEWIC status } \\
\text { appraisal summary on the Southern Maidenhair Fern } \\
\text { Adiantum capillus-veneris in Canada. Ottawa: } \\
\text { Committee on the Status of Endangered Wildlife in } \\
\text { Canada. }\end{array}$ \\
\hline Agalinis aspera & $\begin{array}{l}\text { Hughes, M. (2006). COSEWIC assessment and status } \\
\text { report on the rough agalinis Agalinis aspera in Canada. } \\
\text { Ottawa: Committee on the Status of Endangered Wildlife } \\
\text { in Canada. }\end{array}$ \\
\hline Agalinis skinneriana & $\begin{array}{l}\text { Bowles, J. M., White, R. C., \& Jacobs, C. R. (2010). } \\
\text { COSEWIC assessment and status report on the Skinner's } \\
\text { Agalinis, Agalinis skinneriana in Canada. Ottawa: } \\
\text { Committee on the Status of Endangered Wildlife in } \\
\text { Canada. }\end{array}$ \\
\hline Ammannia robusta & $\begin{array}{l}* \text { no longer available publicly, available on request from } \\
\text { the COSEWIC Secretariat }\end{array}$ \\
\hline Antennaria Flagellaris & $\begin{array}{l}\text { Douglas, G. W., Penny, J. L., \& Barton, K. (2004). } \\
\text { COSEWIC status report on the stoloniferous pussytoes } \\
\text { Antennaris flagellaris in Canada. Ottawa: Committee on } \\
\text { the Status of Endangered Wildlife in Canada. }\end{array}$ \\
\hline Azolla mexicana & $\begin{array}{l}\text { Klinkenberg, B. (2008). COSEWIC assessment and } \\
\text { update status report on the Mexican Mosquito-fern } \\
\text { Azolla mexicana in Canad. Committee on the Status of } \\
\text { Endangered Wildlife in Canada. }\end{array}$ \\
\hline Balsamorhiza deltoidea & $\begin{array}{l}\text { Fairbarns, M. (2009). COSEWIC assessment and update } \\
\text { status report on the Deltoid Balsamroot, Balsamorhiza } \\
\text { deltoidea in Canada. Ottawa: Committee on the Status of } \\
\text { Endangered Wildlife in Canada. }\end{array}$ \\
\hline Bartonia paniculata ssp. paniculata & $\begin{array}{l}\text { COSEWIC. (2003f). COSEWIC assessment and update } \\
\text { status report on the branched bartonia Bartonia } \\
\text { paniculata ssp. paniculata in Canada. Ottawa: } \\
\text { Committee on the Status of Endangered Wildlife in } \\
\text { Canada. }\end{array}$ \\
\hline Betula lenta & $\begin{array}{l}\text { COSEWIC. (2006a). COSEWIC assessment and status } \\
\text { report on the cherry birch Betula lenta in Canada. } \\
\text { Ottawa: Committee on the Status of Endangered Wildlife } \\
\text { in Canada. }\end{array}$ \\
\hline Bouteloua dactyloides & $\begin{array}{l}\text { COSEWIC. (2011c). COSEWIC assessment and status } \\
\text { report on the Buffalograss Bouteloua dactyloides in } \\
\text { Canada. Ottawa: Committee on the Status of } \\
\text { Endangered Wildlife in Canada. }\end{array}$ \\
\hline
\end{tabular}




\begin{tabular}{|c|c|}
\hline Buchnera americana & $\begin{array}{l}\text { COSEWIC. (2011b). COSEWIC assessment and status } \\
\text { report on the Bluehearts Buchnera americana } \\
\text { in Canada. Ottawa: Committee on the Status of } \\
\text { Endangered Wildlife in Canada. }\end{array}$ \\
\hline Calochortus lyallii & $\begin{array}{l}\text { COSEWIC. (2011e). COSEWIC assessment and status } \\
\text { report on the Lyall's Mariposa Lily Calochortus lyallii in } \\
\text { Canada. Ottawa: Committee on the Status of } \\
\text { Endangered Wildlife in Canada. }\end{array}$ \\
\hline Camassia scilloides & $\begin{array}{l}\text { COSEWIC. (2002h). COSEWIC assessment and update } \\
\text { status report on the wild hyacinth Camassia scilloides in } \\
\text { Canada. Ottawa: Committee on the Status of } \\
\text { Endangered Wildlife in Canada. }\end{array}$ \\
\hline Camissonia contorta & $\begin{array}{l}\text { COSEWIC. (2006c). COSEWIC assessment and status } \\
\text { report on the contorted-pod evening } \\
\text { primrose Camissonia contorta in Canada. Ottawa: } \\
\text { Committee on the Status of Endangered Wildlife in } \\
\text { Canada. }\end{array}$ \\
\hline Carex juniperorum & $\begin{array}{l}\text { * no longer available publicly, available on request from } \\
\text { the COSEWIC Secretariat }\end{array}$ \\
\hline Carex lupuliformis & $\begin{array}{l}\text { COSEWIC. (2011d). COSEWIC assessment and status } \\
\text { report on the False Hop Sedge Carex lupuliformis in } \\
\text { Canada. Ottawa: Committee on the Status of } \\
\text { Endangered Wildlife in Canada. }\end{array}$ \\
\hline Carex sabulosa & $\begin{array}{l}\text { COSEWIC. (2005a). COSEWIC assessment and status } \\
\text { report on the baikal sedge Carex sabulosa in Canada. } \\
\text { Ottawa: Committee on the Status of Endangered Wildlife } \\
\text { in Canada. }\end{array}$ \\
\hline Carex tumulicola & $\begin{array}{l}\text { COSEWIC. (2008a). COSEWIC assessment and status } \\
\text { report on the foothill sedge Carex tumulicola in Canada. } \\
\text { Ottawa: Committee on the Status of Endangered Wildlife } \\
\text { in Canada. }\end{array}$ \\
\hline Castanea dentata & $\begin{array}{l}\text { COSEWIC 2004. COSEWIC assessment and status } \\
\text { report on the American chestnut Castanea dentata in } \\
\text { Canada. Committee on the Status of Endangered } \\
\text { Wildlife in Canada. Ottawa. vi }+19 \text { pp. }\end{array}$ \\
\hline Castilleja levisecta & $\begin{array}{l}\text { COSEWIC. (2007b). COSEWIC assessment and update } \\
\text { status report on the golden paintbrush Castilleja } \\
\text { levisecta in Canada. Ottawa: Committee on the Status of } \\
\text { Endangered Wildlife in Canada. }\end{array}$ \\
\hline Castilleja rupicola & $\begin{array}{l}\text { COSEWIC. (2005c). COSEWIC assessment and status } \\
\text { report on the cliff paintbrush Castilleja rupicola in } \\
\text { Canada. Ottawa: Committee on the Status of } \\
\text { Endangered Wildlife in Canada. }\end{array}$ \\
\hline Castilleja victoriae & $\begin{array}{l}\text { COSEWIC. (2010f). COSEWIC assessment and status } \\
\text { report on the Victoria's Owl-clover Castilleja } \\
\text { victoriae in Canada. Ottawa: Committee on the Status of } \\
\text { Endangered Wildlife in Canada. }\end{array}$ \\
\hline Celtis tenuifolia & $\begin{array}{l}\text { COSEWIC. (2003g). COSEWIC assessment and update } \\
\text { status report on the dwarf hackberry Celtis tenuifolia in } \\
\text { Canada. Ottawa: Committee on the Status of } \\
\text { Endangered Wildlife in Canada. }\end{array}$ \\
\hline Centaurium muehlenbergii & $\begin{array}{l}\text { COSEWIC. (2008e). COSEWIC assessment and status } \\
\text { report on the Muhlenberg's centaury, Centaurium }\end{array}$ \\
\hline
\end{tabular}




\begin{tabular}{|c|c|}
\hline & $\begin{array}{l}\text { muehlenbergii in Canada. Committee on the Status of } \\
\text { Endangered Wildlife in Canada. }\end{array}$ \\
\hline Chenopodium subglabrum & $\begin{array}{l}\text { COSEWIC. (2006g). COSEWIC assessment and update } \\
\text { status report on the smooth goosefoot Chenopodium } \\
\text { subglabrum in Canada. Committee on the Status of } \\
\text { Endangered Wildlife in Canada. }\end{array}$ \\
\hline Cirsium hillii & $\begin{array}{l}\text { COSEWIC. (2004d). COSEWIC assessment and status } \\
\text { report on Hill's thistle Cirsium hillii in } \\
\text { Canada Committee on the Status of Endangered Wildlife } \\
\text { in Canada. }\end{array}$ \\
\hline Cirsium pitcheri & $\begin{array}{l}\text { COSEWIC. (2010e). COSEWIC assessment and status } \\
\text { report on Pitcher's Thistle Cirsium pitcheri in Canada. } \\
\text { Committee on the Status of Endangered Wildlife in } \\
\text { Canada. }\end{array}$ \\
\hline Collomia tenella & $\begin{array}{l}\text { Forsyth, R. G., \& Ovaska, K. E. (2003). COSEWIC } \\
\text { assessment and status report on the slender } \\
\text { collomia Collomia tenella in Canada. Committee on the } \\
\text { Status of Endangered Wildlife in Canada. }\end{array}$ \\
\hline Cornus florida & $\begin{array}{l}\text { Ambrose, J. (2007). COSEWIC assessment and status } \\
\text { report on the eastern flowering dogwood Cornus } \\
\text { florida in Canada. Ottawa: Committee on the Status of } \\
\text { Endangered Wildlife in Canada. }\end{array}$ \\
\hline Cryptantha minima & $\begin{array}{l}\text { Michalsky, S. (2000). COSEWIC assessment and status } \\
\text { report on the tiny cryptanthe Cryptantha minima in } \\
\text { Canada Ottawa: Committee on the Status of Endangered } \\
\text { Wildlife in Canada. }\end{array}$ \\
\hline Dalea villosa & $\begin{array}{l}\text { Hamm, H. P. (2011). COSEWIC assessment and status } \\
\text { report on the Hairy Prairie-clover Dalea villosa in } \\
\text { Canada. Ottawa: Committee on the Status of } \\
\text { Endangered Wildlife in Canada. }\end{array}$ \\
\hline Drosera filiformis & $\begin{array}{l}\text { Freedman, B., \& Jotcham, J. (2001). COSEWIC } \\
\text { assessment and update status report on the thread-leaved } \\
\text { sundew Drosera filiformis in Canada. Ottawa: } \\
\text { Committee on the Status of Endangered Wildlife in } \\
\text { Canada. }\end{array}$ \\
\hline Eleocharis geniculata (great lake plains) & $\begin{array}{l}\text { McIntosh, T., Oldham, M. J., \& Björk, C. (2009). } \\
\text { COSEWIC assessment and status report on the Bent } \\
\text { Spike-rush Eleocharis geniculata, Great Lakes Plains } \\
\text { population and Southern Mountain population, } \\
\text { in Canada. Ottawa: Committee on the Status of } \\
\text { Endangered Wildlife in Canada. }\end{array}$ \\
\hline Enemion biternatum & $\begin{array}{l}\text { Thompson, M. J. (2005). COSEWIC assessment and } \\
\text { update status report on the false rue-anemone Enemion } \\
\text { biternatum in Canada. Ottawa: Committee on the Status } \\
\text { of Endangered Wildlife in Canada. }\end{array}$ \\
\hline Epilobium torreyi & $\begin{array}{l}\text { Fairbarns, M., Costanzo, B., Adolf, A., \& Ceska, O. } \\
\text { (2006). COSEWIC assessment and status report on the } \\
\text { brook spike-primrose Epilobium torreyi in Canada. } \\
\text { Ottawa: Committee on the Status of Endangered Wildlife } \\
\text { in Canada. }\end{array}$ \\
\hline Eurybia divaricata & $\begin{array}{l}\text { Thompson, M. J. (2002). COSEWIC assessment and } \\
\text { update status report on the white wood aster Eurybia } \\
\text { divaricata in Canada. Ottawa: Committee on the Status }\end{array}$ \\
\hline
\end{tabular}




\begin{tabular}{|c|c|}
\hline & of Endangered Wildlife in Canada. \\
\hline Frasera caroliniensis & $\begin{array}{l}\text { Smith, T. W., Rothfels, C., \& Oberndorfer, E. (2006). } \\
\text { COSEWIC assessment and update status report on the } \\
\text { American Columbo Frasera caroliniensis in } \\
\text { Canada Ottawa: Committee on the Status of Endangered } \\
\text { Wildlife in Canada. }\end{array}$ \\
\hline Gentiana alba & $\begin{array}{l}\text { Bowles, J. M., \& Jacobs, C. R. (2010). } \\
\text { COSEWIC assessment and status report on the White } \\
\text { Prairie Gentian Canada. Ottawa: Committee on the } \\
\text { Status of Endangered Wildlife in Canada. }\end{array}$ \\
\hline Geum peckii & $\begin{array}{l}\text { Blaney, S. (2010). COSEWIC assessment and status } \\
\text { report on the Eastern Mountain Avens Geum peckii in } \\
\text { Canada. Ottawa: Committee on the Status of } \\
\text { Endangered Wildlife in Canada. }\end{array}$ \\
\hline Hymenoxys herbacea & $\begin{array}{l}\text { Campbell, L. B., Oldham, M. J., \& Oldham, H. (2002). } \\
\text { COSEWIC assessment and status report the lakeside } \\
\text { daisy Hymenoxys herbacea in Canada. Ottawa: } \\
\text { Committee on the Status of Endangered Wildlife in } \\
\text { Canada. }\end{array}$ \\
\hline Isoetes bolanderi & $\begin{array}{l}\text { Brunton, D. F., \& Achuff, P. L. (2006). COSEWIC } \\
\text { assessment and update status report on the Bolander's } \\
\text { quillwort Isoetes bolanderi in Canada. Ottawa: } \\
\text { Committee on the Status of Endangered Wildlife in } \\
\text { Canada. }\end{array}$ \\
\hline Isoetes engelmannii & $\begin{array}{l}* \text { no longer available publicly, available on request from } \\
\text { the COSEWIC Secretariat }\end{array}$ \\
\hline Isotria medeoloides & $\begin{array}{l}\text { Brinker, S. R. (2011). COSEWIC status appraisal } \\
\text { summary on the Small Whorled Pogonia Isotria } \\
\text { medeoloides in Canada. Ottawa: Committee on the } \\
\text { Status of Endangered Wildlife in Canada. }\end{array}$ \\
\hline Juncus kelloggii & $\begin{array}{l}\text { Costanzo, B. (2003). COSEWIC assessment and status } \\
\text { report on Kellogg's rush Juncus kelloggii in Canada. } \\
\text { Ottawa: Committee on the Status of Endangered Wildlife } \\
\text { in Canada. }\end{array}$ \\
\hline Liatris spicata & $\begin{array}{l}\text { COSEWIC. (2010b). COSEWIC assessment and status } \\
\text { report on the Dense Blazing Star Liatris spicata in } \\
\text { Canada. Committee on the Status of Endangered Wildlife } \\
\text { in Canada, ix }+23 \text { pp. }\end{array}$ \\
\hline Liparis liliifolia & $\begin{array}{l}\text { COSEWIC. (2010d). COSEWIC assessment and status } \\
\text { report on the Purple Twayblade Liparis liliifolia in } \\
\text { Canada. Committee on the Status of Endangered } \\
\text { Wildlife, xii, }+25 \text { pp. }\end{array}$ \\
\hline Lipocarpha micrantha & $\begin{array}{l}\text { COSEWIC. (2002d). COSEWIC assessment and update } \\
\text { status report on the small-flowered lipocarpha } \\
\text { Lipocarpha micrantha in Canada. Committee on the } \\
\text { Status of Endangered Wildlife in Canada. Ottawa, vi, + } \\
16 \text { pp. }\end{array}$ \\
\hline Lomantium grayi & $\begin{array}{l}\text { COSEWIC. (2008c). COSEWIC assessment and status } \\
\text { report on the Gray's Desert-parsley Lomatium grayi in } \\
\text { Canada. Committee on the Status of Endangered Wildife } \\
\text { in Canada (vi), }+27 \text { pp. }\end{array}$ \\
\hline Lophiola aurea & $\begin{array}{l}\text { COSEWIC. (2012a). COSEWIC assessment and status } \\
\text { report on the Goldencrest Lophiola aurea in Canada. } \\
\text { Committee on the Status of Endangered Wildlife in }\end{array}$ \\
\hline
\end{tabular}




\begin{tabular}{|c|c|}
\hline & Canada, xi, + $37 \mathrm{pp}$. \\
\hline Lotus formosissimus & $\begin{array}{l}\text { COSEWIC. COSEWIC assessment and status report on } \\
\text { the Seaside Birds-foot LotusLotus formosissimus in } \\
\text { Canada. Committee on the Status of Endangered Wildlife } \\
\text { in Canada(ix) }+19 \text { pp. }\end{array}$ \\
\hline Lotus pinnatus & $\begin{array}{l}\text { COSEWIC. (2004a). COSEWIC assessment and status } \\
\text { report on the bog bird's-foot trefoil Lotus pinnatus in } \\
\text { Canada. Committee on the Status of Endangered Wildlife } \\
\text { in Canada, vi, }+33 \text { pp. }\end{array}$ \\
\hline Lupinus densiflorus & $\begin{array}{l}\text { COSEWIC. (2005d). COSEWIC assessment and status } \\
\text { report on the dense-flowered lupine Lupinus densiflorus } \\
\text { in Canada. Committee on the Status of Endangered } \\
\text { Wildlife in Canada, vi, }+21 \mathrm{pp} \text {. }\end{array}$ \\
\hline Lupinus lepidus & $\begin{array}{l}\text { COSEWIC. (2009a). COSEWIC assessment and status } \\
\text { on the Prairie Lupine Lupinus lepidusvar. lepidus in } \\
\text { Canada. COSEWIC assessment and status on the Prairie } \\
\text { Lupine Lupinus lepidusvar. lepidus in Canada, vi, }+34 \\
\text { pp. }\end{array}$ \\
\hline Lupinus oreganus & $\begin{array}{l}* \text { no longer available publicly, available on request from } \\
\text { the COSEWIC Secretariat }\end{array}$ \\
\hline lupinus rivularis & $\begin{array}{l}\text { COSEWIC. (2002a). COSEWIC assessment and status } \\
\text { report on the streambank lupine Lupinus rivularis in } \\
\text { Canada. Committee on the Status of Endangered Wildlife } \\
\text { in Canada, vi, }+36 \mathrm{pp} \text {. }\end{array}$ \\
\hline Magnolia acuminata & $\begin{array}{l}\text { COSEWIC. (2010a). COSEWIC assessment and status } \\
\text { report on the Cucumber Tree Magnolia acuminata in } \\
\text { Canada. Committee on the Status of Endangered Wildlife } \\
\text { in Canada, } x,+10 \mathrm{pp} \text {. }\end{array}$ \\
\hline Meconella oregana & $\begin{array}{l}\text { COSEWIC. }(2005 \mathrm{~g}) \text {. COSEWIC assessment and status } \\
\text { report on the white meconella Meconella oreganain } \\
\text { Canada. } v i,+25 \mathrm{pp} \text {. }\end{array}$ \\
\hline Microseris bigelovii & $\begin{array}{l}\text { COSEWIC. (2006b). COSEWIC assessment and status } \\
\text { report on the coast microseris Microseris bigeloviiin } \\
\text { Canada. Committee on the Status of Endangered Wildlife } \\
\text { in Canada, vi, }+26 \mathrm{pp} \text {. }\end{array}$ \\
\hline Minuartia pusilla & $\begin{array}{l}\text { COSEWIC. (2004b). COSEWIC assessment and status } \\
\text { report on the dwarf sandwort Minuartia pusilla in } \\
\text { Canada. Committee on the Status of Endangered Wildlife } \\
\text { in Canada, vi, }+17 \mathrm{pp} \text {. }\end{array}$ \\
\hline Orthocarpus barbatus & $\begin{array}{l}\text { COSEWIC. (2005e). COSEWIC assessment and status } \\
\text { report on the Grand Coulee Owl-clover Orthocarpus } \\
\text { barbatus in Canada. Committee on the Status of } \\
\text { Endangered Wildlife in Canada, vi, }+17 \mathrm{pp} .\end{array}$ \\
\hline Orthocarpus bracteosus & $\begin{array}{l}\text { COSEWIC. (2004c). COSEWIC assessment and status } \\
\text { report on the rosy owl-clover Orthocarpus bracteosus in } \\
\text { Canada. Committee on the Status of Endangered Wildlife } \\
\text { in Canada, vi, }+18 \mathrm{pp} \text {. }\end{array}$ \\
\hline Phacelia ramosissima & $\begin{array}{l}\text { COSEWIC. (2005b). COSEWIC assessment and status } \\
\text { report on the branched phacelia Phacelia ramosissima in } \\
\text { Canada. Committee on the Status of Endangered Wildlife } \\
\text { in Canada, vi, }+18 \mathrm{pp} \text {. }\end{array}$ \\
\hline Phlox speciosa & $\begin{array}{l}\text { * no longer available publicly, available on request from } \\
\text { the COSEWIC Secretariat }\end{array}$ \\
\hline Plagiobothrys figuratus & $\begin{array}{l}\text { COSEWIC. (2008b). COSEWIC assessment and status } \\
\text { report on the fragrant popcornflower Plagiobothrys }\end{array}$ \\
\hline
\end{tabular}




\begin{tabular}{|c|c|}
\hline & $\begin{array}{l}\text { figuratus in Canada. Committee on the Status of } \\
\text { Endangered Wildlife in Canada, vi, }+23 \mathrm{pp} .\end{array}$ \\
\hline Plagiobothrys tenellus & $\begin{array}{l}\text { COSEWIC. (2008f). COSEWIC assessment and status } \\
\text { report on the Slender Popcornflower Plagiobothrys } \\
\text { tenellus in Canada. Committee on the Status of } \\
\text { Endangered Wildlife in Canada, vi, }+23 \mathrm{pp} \text {. }\end{array}$ \\
\hline Plantago cordata & $\begin{array}{l}\text { COSEWIC. (2000). COSEWIC assessment and update } \\
\text { status report on Heart-leaved Plantain Plantago cordata } \\
\text { in Canada. Committee on the Status of Endangered } \\
\text { Wildlife in Canada, vi, }+14 \mathrm{pp} .\end{array}$ \\
\hline Platanthera leucophaea & $\begin{array}{l}\text { COSEWIC. (2003h). COSEWIC assessment and update } \\
\text { status report on the eastern prairie fringed-orchid } \\
\text { Platanthera leucophaea in Canada. Committee on the } \\
\text { Status of Endangered Wildlife in Canada, vi, }+27 \mathrm{pp} \text {. }\end{array}$ \\
\hline Polemonium vanbruntiae & $\begin{array}{l}\text { COSEWIC. (2002f). COSEWIC assessment and update } \\
\text { status report on the van Brunt's Jacob's-ladder } \\
\text { Polemonium vanbruntiae. Committee on the Status of } \\
\text { Endangered Wildlife in Canada, vi, }+22 \mathrm{pp} \text {. }\end{array}$ \\
\hline Polygala incarnata & $\begin{array}{l}\text { COSEWIC. (2009c). COSEWIC assessment and status } \\
\text { report on thePink Milkwort Polygala incarnata in } \\
\text { Canada. Committee on the Status of Endangered Wildlife } \\
\text { in Canada, vii, }+24 \text { pp. }\end{array}$ \\
\hline Polystichum lemmonii & $\begin{array}{l}\text { COSEWIC. (2003b). COSEWIC assessment and status } \\
\text { report on Lemmon's holly fern Polystichum lemmonii in } \\
\text { Canada. Committee on the Status of Endangered Wildlife } \\
\text { in Canada, vi, }+13 \mathrm{pp} \text {. }\end{array}$ \\
\hline Polystichum scopulinum & $\begin{array}{l}\text { COSEWIC. (2005f). COSEWIC assessment and status } \\
\text { report on the mountain holly fern Polystichum } \\
\text { scopulinumin Canada. Committee on the Status of } \\
\text { Endangered Wildlife in Canada, vii, }+18 \mathrm{pp} .\end{array}$ \\
\hline Potamogeton ogdenii & $\begin{array}{l}\text { COSEWIC. (2007a). COSEWIC assessment and status } \\
\text { report on the Ogden's pondweed Potamogeton ogdenii in } \\
\text { Canada. Ottawa: Committee on the Status of } \\
\text { Endangered Wildlife in Canada. }\end{array}$ \\
\hline Psilocarphus brevissimus & $\begin{array}{l}\text { COSEWIC. (2006f). COSEWIC assessment and update } \\
\text { status report on the dwarf woolly-heads Psilocarphus } \\
\text { brevissimus Southern Mountain population and Prairie } \\
\text { population, in Canada. Ottawa. }\end{array}$ \\
\hline Ptelea trifoliata & $\begin{array}{l}\text { COSEWIC. }(2002 \mathrm{c}) . \text { COSEWIC assessment and update } \\
\text { status report on the common hoptree Ptelea trifoliata in } \\
\text { Canada. Ottawa: Committee on the Status of } \\
\text { Endangered Wildlife in Canada. }\end{array}$ \\
\hline Ranunculus alismifolius & $\begin{array}{l}\text { COSEWIC. (2009e). COSEWIC assessment and update } \\
\text { status report on the Water-plantain } \\
\text { Buttercup Ranunculus alismifolius in Canada. Ottawa: } \\
\text { Committee on the Status of Endangered Wildlife in } \\
\text { Canada. }\end{array}$ \\
\hline Ranunculus Californicus & $\begin{array}{l}\text { COSEWIC. (2008g). COSEWIC assessment and status } \\
\text { report on the California Buttercup Ranunculus } \\
\text { californicus in Canada. Ottawa: Committee on the Status } \\
\text { of Endangered Wildlife in Canada. }\end{array}$ \\
\hline Salix chlorolepis & $\begin{array}{l}\text { COSEWIC. (2006d). COSEWIC assessment and status } \\
\text { report on the green-scaled willow Salix chlorolepis in } \\
\text { Canada. Ottawa: Committee on the Status of } \\
\text { Endangered Wildlife in Canada. }\end{array}$ \\
\hline
\end{tabular}




\begin{tabular}{|c|c|}
\hline Sanicula arctopoides & $\begin{array}{l}\text { Donovan, M. T., \& Douglas, G. W. (In Press). } \\
\text { COSEWIC status report on the bear's-foot sanicle } \\
\text { Sanicula arctopoides in Canada. Ottawa. }\end{array}$ \\
\hline Sanicula bipinnatifida & $\begin{array}{l}\text { Penny, J. L., \& Douglas, G. W. (In Press). COSEWIC } \\
\text { status report on the purple sanicle Sanicula bipinnatifida } \\
\text { in Canada. Ottawa. }\end{array}$ \\
\hline Sida hermaphrodita & $\begin{array}{l}\text { COSEWIC. }(2010 \mathrm{~g}) . \text { COSEWIC assessment and status } \\
\text { report on the Virginia Mallow Sida hermaphrodita in } \\
\text { Canada. Ottawa. }\end{array}$ \\
\hline Silene Scouler ssp.grandis & $\begin{array}{l}\text { COSEWIC. (2003c). COSEWIC assessment and status } \\
\text { report on the coastal Scouler's catchfly Silene } \\
\text { scouleri ssp.grandis in Canada. Ottawa: Committee on } \\
\text { the Status of Endangered Wildlife in Canada. }\end{array}$ \\
\hline Silene spaldingii & $\begin{array}{l}\text { * no longer available publicly, available on request from } \\
\text { the COSEWIC Secretariat }\end{array}$ \\
\hline Smilax rotundifolia & $\begin{array}{l}\text { COSEWIC. (2007c). COSEWIC assessment and update } \\
\text { status report on the round-leaved greenbrier (Great Lakes } \\
\text { Plains and Atlantic population) Smilax rotundifolia in } \\
\text { Canada (pp. vi - 32). Ottawa, Canada: Committee on the } \\
\text { Status of Endangered Wildlife in Canada. }\end{array}$ \\
\hline Stylohorun diphyllum & $\begin{array}{l}\text { COSEWIC. (2007d). COSEWIC assessment and update } \\
\text { status report on the wood-poppy Stylophorum diphyllum } \\
\text { in Canada (pp. vi - 23). Ottawa, Canada: Committee on } \\
\text { the Status of Endangered Wildlife in Canada. }\end{array}$ \\
\hline Symphyotrichum frondosum & $\begin{array}{l}\text { COSEWIC. (2006e). COSEWIC assessment and status } \\
\text { report on the short-rayed alkali aster Symphyotrichum } \\
\text { frondosum in Canada (pp. vi - 22). Ottawa, Canada: } \\
\text { Committee on the Status of Endangered Wildlife in } \\
\text { Canada. }\end{array}$ \\
\hline Symphyotrichum praeltum & $\begin{array}{l}\text { COSEWIC. (2003e). COSEWIC assessment and status } \\
\text { report on the willowleaf aster Symphyotrichum } \\
\text { praealtum in Canada (pp. vi - 16). Ottawa, Canada: } \\
\text { Committee on the Status of Endangered Wildlife in } \\
\text { Canada. }\end{array}$ \\
\hline Symphyotrichum Laurentianum & $\begin{array}{l}\text { COSEWIC. (2004f). COSEWIC assessment and update } \\
\text { status report on the Gulf of St. Lawrence } \\
\text { aster Symphyotrichum laurentianum in Canada. Ottawa: } \\
\text { Committee on the Status of Endangered Wildlife in } \\
\text { Canada. }\end{array}$ \\
\hline Symphyotrichum prenanthoides & $\begin{array}{l}\text { COSEWIC. (2012b). COSEWIC assessment and status } \\
\text { report on the Crooked-stem Aster Symphyotrichum } \\
\text { prenanthoides in Canada. Ottawa: Committee on the } \\
\text { Status of Endangered Wildlife in Canada. }\end{array}$ \\
\hline Tephrosia virginiana & $\begin{array}{l}\text { COSEWIC. (2009b). COSEWIC assessment and status } \\
\text { report on the Virginia Goat's-rue Tephrosia virginiana in } \\
\text { Canada (pp. vii - 31). Ottawa, Canada: Committee on the } \\
\text { Status of Endangered Wildlife in Canada. }\end{array}$ \\
\hline Tonella tonella & $\begin{array}{l}\text { COSEWIC. (2003d). COSEWIC assessment and status } \\
\text { report on the small-flowered tonella Tonella tenella in } \\
\text { Canada (pp. vii - 14). Ottawa, Canada: Committee on the } \\
\text { Status of Endangered Wildlife in Canada. }\end{array}$ \\
\hline Tradescantia occidentalis & $\begin{array}{l}\text { COSEWIC. (2002g). COSEWIC assessment and update } \\
\text { status report on the Western spiderwort Tradescantia } \\
\text { occidentalis in Canada. Ottawa, Canada: Committee on } \\
\text { the Status of Endangered Wildlife in Canada. }\end{array}$ \\
\hline
\end{tabular}




\begin{tabular}{|c|c|}
\hline Trillium flexipes & $\begin{array}{l}\text { COSEWIC. (2009d). COSEWIC assessment and update } \\
\text { status report on the Drooping Trillium Trillium flexipesin } \\
\text { Canada (pp. vi - 31). Ottawa, Canada: Committee on the } \\
\text { Status of Endangered Wildlife in Canada. }\end{array}$ \\
\hline Triphora trianthophoros & $\begin{array}{l}\text { COSEWIC. (2010c). COSEWIC assessment and status } \\
\text { report on the Nodding Pogonia Triphora trianthophoros } \\
\text { (pp. vi - 9). Ottawa, Canada: Committee on the Status of } \\
\text { Endangered Wildlife in Canada. }\end{array}$ \\
\hline Triphysaria versicolor & $\begin{array}{l}\text { COSEWIC. (2011a). COSEWIC assessment and status } \\
\text { report on the Bearded Owl-clover Triphysaria } \\
\text { versicolour in Canada (pp. viii - 18). Ottawa, Canada: } \\
\text { Committee on the Status of Endangered Wildlife in } \\
\text { Canada. }\end{array}$ \\
\hline Tripterocalyx micranthus & $\begin{array}{l}\text { COSEWIC. (2002e). COSEWIC assessment and update } \\
\text { status report on the small-flowered sand-verbena } \\
\text { Tripterocalyx micranthus in Canada. (pp. vi - 26). } \\
\text { Ottawa, Canada. }\end{array}$ \\
\hline Triteleia howellii & $\begin{array}{l}\text { COSEWIC. (2003a). COSEWIC assessment and status } \\
\text { report on Howell's triteleia Triteleia howellii in Canada } \\
\text { (pp. vii - 16). Ottawa, Canada: Committee on the Status } \\
\text { of Endangered Wildlife in Canada. }\end{array}$ \\
\hline Uropappus lindleyi & $\begin{array}{l}\text { COSEWIC. (2008d). COSEWIC assessment and status } \\
\text { report on the Lindley's false silverpuffs Uropappus } \\
\text { lindleyi in Canada (pp. vii - 22). Ottawa, Canada: } \\
\text { Committee for the Status of Endangered Wildlife in } \\
\text { Canada. }\end{array}$ \\
\hline Vaccinium stamineum & $\begin{array}{l}\text { White, D. J., \& Oldham, M. J. (In Press). Update } \\
\text { COSEWIC status report on the deerberry Vaccinium } \\
\text { stamineum in Canada. Ottawa. }\end{array}$ \\
\hline Viola pedata & $\begin{array}{l}\text { COSEWIC. (2002b). COSEWIC assessment and update } \\
\text { status report on the bird's-foot violet Viola pedata in } \\
\text { Canada (pp. vi - 13). Ottawa, Canada: Committee for the } \\
\text { Status of Endangered Wildlife in Canada. }\end{array}$ \\
\hline Viola praemorsa ssp. praemorsa & $\begin{array}{l}\text { COSEWIC. (2007e). COSEWIC assessment and update } \\
\text { status report on the yellow montane violet, praemorsa } \\
\text { subspecies, Viola praemorsa ssp. praemorsa in Canada } \\
\text { (pp. vii - 24). Ottawa, Canada: Committee on the Status } \\
\text { of Endangered Wildlife in Canada. }\end{array}$ \\
\hline Woodsia obtusa & $\begin{array}{l}\text { Consaul, L. L. (1994). COSEWIC status report on the } \\
\text { blunt-lobed woodsia Woodsia obtusa in Canada. Ottawa. }\end{array}$ \\
\hline
\end{tabular}


A-3: COSEWIC-listed at-risk plant species $(\mathrm{N}=103)$ summarized by 4 traits I suggest may make them more likely to report missing data $(0=$ no, $1=$ yes $)$, ranked by total number of traits had. The species at the end of this list are examples of species I would suggest need the greatest further investigation into population characteristics.

\begin{tabular}{|c|c|c|c|c|c|}
\hline Scientific name & Annual? & $\begin{array}{c}\text { Herbaceous } \\
\quad ?\end{array}$ & $\begin{array}{c}\text { Pop size } \\
\text { fewer than } \\
500 ?\end{array}$ & $\begin{array}{c}\text { Total pop } \\
\text { fragmented } \\
?\end{array}$ & $\begin{array}{l}\text { \# Traits } \\
\text { had }\end{array}$ \\
\hline Antennaria Flagellaris & 0 & 0 & 0 & 0 & 0 \\
\hline Balsamorhiza deltoidea & 0 & 0 & 0 & 0 & 0 \\
\hline Bouteloua dactyloides & 0 & 0 & 0 & 0 & 0 \\
\hline Camassia scilloides & 0 & 0 & 0 & 0 & 0 \\
\hline Carex sabulosa & 0 & 0 & 0 & 0 & 0 \\
\hline Castilleja levisecta & 0 & 0 & 0 & 0 & 0 \\
\hline Cirsium pitcheri & 0 & 0 & 0 & 0 & 0 \\
\hline Dalea villosa & 0 & 0 & 0 & 0 & 0 \\
\hline Geum peckii & 0 & 0 & 0 & 0 & 0 \\
\hline Isoetes engelmannii & 0 & 0 & 0 & 0 & 0 \\
\hline Liatris spicata & 0 & 0 & 0 & 0 & 0 \\
\hline Lomantium grayi & 0 & 0 & 0 & 0 & 0 \\
\hline Lophiola aurea & 0 & 0 & 0 & 0 & 0 \\
\hline Lupinus oreganus & 0 & 0 & 0 & 0 & 0 \\
\hline Phlox speciosa & 0 & 0 & 0 & 0 & 0 \\
\hline Polystichum lemmonii & 0 & 0 & 0 & 0 & 0 \\
\hline Potamogeton ogdenii & 0 & 0 & 0 & 0 & 0 \\
\hline Ranunculus Californicus & 0 & 0 & 0 & 0 & 0 \\
\hline Sida hermaphrodita & 0 & 0 & 0 & 0 & 0 \\
\hline $\begin{array}{c}\text { Symphyotrichum } \\
\text { prenanthoides }\end{array}$ & 0 & 0 & 0 & 0 & 0 \\
\hline Trillium flexipes & 0 & 0 & 0 & 0 & 0 \\
\hline Triphora trianthophoros & 0 & 0 & 0 & 0 & 0 \\
\hline Vaccinium stamineum & 0 & 0 & 0 & 0 & 0 \\
\hline Viola pedata & 0 & 0 & 0 & 0 & 0 \\
\hline $\begin{array}{l}\text { Adiantum capillus- } \\
\text { veneris }\end{array}$ & 0 & 0 & 1 & 0 & 1 \\
\hline Agalinis skinneriana & 1 & 0 & 0 & 0 & 1 \\
\hline Azolla mexicana & 1 & 0 & 0 & 0 & 1 \\
\hline Buchnera americana & 0 & 0 & 1 & 0 & 1 \\
\hline Calochortus lyallii & 0 & 0 & 0 & 1 & 1 \\
\hline Carex juniperorum & 0 & 0 & 0 & 1 & 1 \\
\hline Castilleja victoriae & 1 & 0 & 0 & 0 & 1 \\
\hline Cirsium hillii & 0 & 0 & 1 & 0 & 1 \\
\hline Cornus florida & 0 & 0 & 1 & 0 & 1 \\
\hline Cryptantha minima & 1 & 0 & 0 & 0 & 1 \\
\hline Drosera filiformis & 0 & 0 & 0 & 1 & 1 \\
\hline $\begin{array}{l}\text { Eleocharis geniculata } \\
\text { (great lake plains) }\end{array}$ & 1 & 0 & 0 & 0 & 1 \\
\hline
\end{tabular}




\begin{tabular}{|c|c|c|c|c|c|}
\hline Enemion biternatum & 0 & 0 & 0 & 1 & 1 \\
\hline Eurybia divaricata & 0 & 0 & 0 & 1 & 1 \\
\hline Gentiana alba & 0 & 0 & 1 & 0 & 1 \\
\hline Hymenoxys herbacea & 0 & 0 & 0 & 1 & 1 \\
\hline Isoetes bolanderi & 0 & 0 & 0 & 1 & 1 \\
\hline Isotria medeoloides & 0 & 0 & 1 & 0 & 1 \\
\hline Juncus kelloggii & 1 & 0 & 0 & 0 & 1 \\
\hline Liparis liliifolia & 0 & 0 & 1 & 0 & 1 \\
\hline Lotus formosissimus & 0 & 0 & 1 & 0 & 1 \\
\hline Phacelia ramosissima & 0 & 0 & 1 & 0 & 1 \\
\hline Plantago cordata & 0 & 0 & 0 & 1 & 1 \\
\hline Polemonium vanbruntiae & 0 & 0 & 0 & 1 & 1 \\
\hline Polystichum scopulinum & 0 & 0 & 0 & 1 & 1 \\
\hline Salix chlorolepis & 0 & 0 & 1 & 0 & 1 \\
\hline Sanicula arctopoides & 0 & 0 & 0 & 1 & 1 \\
\hline Sanicula bipinnatifida & 0 & 0 & 1 & 0 & 1 \\
\hline Smilax rotundifolia & 0 & 0 & 1 & 0 & 1 \\
\hline $\begin{array}{l}\text { Symphyotrichum } \\
\text { Laurentianum }\end{array}$ & 1 & 0 & 0 & 0 & 1 \\
\hline Tephrosia virginiana & 0 & 0 & 1 & 0 & 1 \\
\hline Tradescantia occidentalis & 0 & 0 & 0 & 1 & 1 \\
\hline Triphysaria versicolor & 1 & 0 & 0 & 0 & 1 \\
\hline Triteleia howellii & 0 & 0 & 1 & 0 & 1 \\
\hline $\begin{array}{l}\text { Viola praemorsa ssp. } \\
\text { praemorsa }\end{array}$ & 0 & 0 & 0 & 1 & 1 \\
\hline Abronia umbellata & 0 & 0 & 1 & 1 & 2 \\
\hline Actaea elata & 0 & 0 & 1 & 1 & 2 \\
\hline Ammannia robusta & 1 & 0 & 0 & 1 & 2 \\
\hline $\begin{array}{c}\text { Bartonia paniculata ssp. } \\
\text { paniculata }\end{array}$ & 1 & 0 & 1 & 0 & 2 \\
\hline Betula lenta & 0 & 0 & 1 & 1 & 2 \\
\hline Camissonia contorta & 1 & 0 & 0 & 1 & 2 \\
\hline Carex lupuliformis & 0 & 0 & 1 & 1 & 2 \\
\hline Carex tumulicola & 0 & 0 & 1 & 1 & 2 \\
\hline Castanea dentata & 0 & 0 & 1 & 1 & 2 \\
\hline Castilleja rupicola & 0 & 0 & 1 & 1 & 2 \\
\hline Celtis tenuifolia & 0 & 0 & 1 & 1 & 2 \\
\hline Epilobium torreyi & 1 & 0 & 1 & 0 & 2 \\
\hline Frasera caroliniensis & 0 & 0 & 1 & 1 & 2 \\
\hline Lipocarpha micrantha & 1 & 0 & 0 & 1 & 2 \\
\hline Lotus pinnatus & 0 & 0 & 1 & 1 & 2 \\
\hline Lupinus densiflorus & 1 & 0 & 0 & 1 & 2 \\
\hline Lupinus lepidus & 0 & 0 & 1 & 1 & 2 \\
\hline lupinus rivularis & 0 & 0 & 1 & 1 & 2 \\
\hline Magnolia acuminata & 0 & 0 & 1 & 1 & 2 \\
\hline Meconella oregana & 1 & 0 & 0 & 1 & 2 \\
\hline Microseris bigelovii & 1 & 0 & 0 & 1 & 2 \\
\hline Orthocarpus barbatus & 1 & 0 & 0 & 1 & 2 \\
\hline
\end{tabular}




\begin{tabular}{|c|c|c|c|c|c|}
\hline Plagiobothrys figuratus & 1 & 0 & 1 & 0 & 2 \\
\hline Plagiobothrys tenellus & 1 & 0 & 1 & 0 & 2 \\
\hline Platanthera leucophaea & 0 & 0 & 1 & 1 & 2 \\
\hline Polygala incarnata & 1 & 0 & 1 & 0 & 2 \\
\hline Psilocarphus brevissimus & 1 & 0 & 0 & 1 & 2 \\
\hline Ptelea trifoliata & 0 & 0 & 1 & 1 & 2 \\
\hline Ranunculus alismifolius & 0 & 0 & 1 & 1 & 2 \\
\hline $\begin{array}{c}\text { Silene Scouler } \\
\text { ssp.grandis }\end{array}$ & 0 & 0 & 1 & 1 & 2 \\
\hline Silene spaldingii & 0 & 0 & 1 & 1 & 2 \\
\hline Stylohorun diphyllum & 0 & 0 & 1 & 1 & 2 \\
\hline $\begin{array}{c}\text { Symphyotrichum } \\
\text { frondosum }\end{array}$ & 1 & 0 & 1 & 0 & 2 \\
\hline $\begin{array}{c}\text { Symphyotrichum } \\
\text { praeltum }\end{array}$ & 0 & 0 & 1 & 1 & 2 \\
\hline Woodsia obtusa & 0 & 0 & 1 & 1 & 2 \\
\hline Agalinis aspera & 1 & 0 & 1 & 1 & 3 \\
\hline $\begin{array}{c}\text { Centaurium } \\
\text { muehlenbergii }\end{array}$ & 1 & 0 & 1 & 1 & 3 \\
\hline $\begin{array}{c}\text { Chenopodium } \\
\text { subglabrum }\end{array}$ & 1 & 0 & 1 & 1 & 3 \\
\hline Collomia tenella & 1 & 0 & 1 & 1 & 3 \\
\hline Minuartia pusilla & 1 & 0 & 1 & 1 & 3 \\
\hline Orthocarpus bracteosus & 1 & 0 & 1 & 1 & 3 \\
\hline Tonella tonella & 1 & 0 & 1 & 1 & 3 \\
\hline Tripterocalyx micranthus & 1 & 0 & 1 & 1 & 3 \\
\hline Uropappus lindleyi & 1 & 0 & 1 & 1 & 3 \\
\hline
\end{tabular}




\section{APPENDIX B: DEFINITIONS}

Area of Occupancy: the estimated amount of ground space all individuals of the species in Canada together take up

At-Risk: A species recognized as needing conservation action in Canada, to be assessed and categorized as either extirpated, endangered, threatened, or special concern

COSEWIC: The Committee on the Status of Endangered Wildlife in Canada, the assessment and listing body for SARA in Canada.

Endangered: According to COSEWIC, a wildlife species facing imminent extirpation or extinction

Extent of Occurrence: the total range of the species in Canada

Extirpated: According to COSEWIC, a wildlife species no longer existing in the wild in Canada, but occurring elsewhere

IUCN: The International Union for the Conservation of Nature, the first world wide conservation authority and listing body, created the standard quantitative criteria commonly used for listing species in nations own protection acts

SARA: The Species At Risk Act, enacted in Canada with the ratification of COSEWIC in 2002 for the listing and protection of all Canadian native wildlife species.

Special Concern: According to COSEWIC, a wildlife species that may become threatened or endangered because of a combination of biological characteristics and identified threats, formerly referred to as Vulnerable

Threatened: According to COSEWIC, a wildlife species likely to become endangered if limiting factors are not reversed

Meta-analysis: a form of statistical analysis where information is extracted from a number of other studies to analyze trends between different findings 


\section{REFERENCES}

Araujo, M. B., \& Guisan, A. (2006). Five (or so) challenges for species distribution modelling. Journal of Biogeography, 33, 1677-1688.

Archaux, F., Berges, L., Chevalier, R. (2007). "Are plant censuses carried out on small quadrats more reliable than on larger ones?" Plant Ecology 188: 179-190. Plant Ecology, 188, 179-190.

Arponen, A. (2012). Prioritizing species for conservation planning. Biodiversity Conservation, 21, 875-893.

Austin, M. P., \& Heyligers, P. C. (1989). Vegetation survey design for conservation: gradsect sampling of forests in north-eastern new south wales. Biological Conservation, 50, 13-32.

Barnett, D. T., \& Stohlgren, T. S. (2003). A nested-intensity design for surveying plant diversity. Biodiversity and Conservation, 12, 255-278.

Barry, S., \& Welsh, A. H. (2001). Distance sampling methodology. Journal of the Royal Statistical Society, Series B, 63(31-53).

Bastin, L., \& Thomas, C. D. (1999). The distribution of plant species in urban vegetation fragments. Landscape Ecology, 14(1), 493-507.

Baur, B., \& Erhardt, A. (1995). Habitat Fragmentation and Habitat Alterations: Principal Threats to Most Animal and Plant Species. GAIA - Ecological Perspectives for Science and Society, 4(4), 221-226.

Bellingham, P. J., \& Sparrow, A. D. (2000). Resprouting as a life history strategy in woody plant communities. Oikos, 89(2), 409-416.

Boersma, P. D., Kareiva, P., Fagan, W. F., Clark, A., \& Hoekstra, J. M. (2001). How good are endangered species recovery plans? BioScience, 51(8), 643-649.

Boswell, G. P., Britton, F., N., \& Franks, N. R. (1998). Habitat fragmentation, percolation theory and the conservation of a keystone species. Proc. R. Soc. Lond. B, 265(1409), 1921-1925.

Bradley, B. A. (2013). Distribution models of invasive plants over-estimate potential impact. Biological Invasions, 15, 1417-1429.

Buckland, S. T., Borchers, D. L., Johnston, A., Henrys, P. A., \& Marques, T. A. (2007). Line transect methods for plant surveys. Biometrics, 63(989-998). 
Environment Canada. (2009). The Status of Wild Species in Canada - Species at Risk Act General Status Report 2003-2008.

Chakravarthy, A. K., Yeshwanth, H. M., Kumar, L. V., Kumar, N. R. P., \& Goel, S. C. (2008). DNA-barcoding and species identification. Emerging trends of researches in insect pest management and environmental safety, I, 55-64.

Clark, J. A., Hoekstra, J. M., Boersma, P. D., \& Kareiva, P. (2002). Improving U.S. Endangered Species Act Recovery Plans: Key Findings and Recommendations of the SCB Recovery Plan Project Conservation Biology, 16(6), 1510-1519.

Conroy, M. J., Runge, J. P., Barker, R. J., Schofield, M. R., \& Fonnesbeck, C. J. (2008). Efficient estimation of abundance for patchily distributed populations via twophase, adaptive sampling. Ecology, 89(12), 3362-3370.

Crall, A. W., Jarnevich, C. S., Panke, B., Young, N., Renz, M., \& Morisette, J. (2013). Using habitat suitability models to target invasive plant species surveys. Ecological Applications, 23(1), 60-72.

Engen, S., Lande, R., \& Saether, B. E. (2003). Demographic stochasticity and allele effects in populations with two sexes. Ecology, 84(9), 2378-2386.

Engler, R., Guisan, A., \& Rechsteiner, L. (2004). An improved approach for predicting the distribution of rare and endangered species from occurrence and pseudoabsence data. Journal of Applied Ecology, 41(2), 263-274.

Ferenc, J., Lui, W., \& Davis, A. J. (2006). Topological keystone species: measures of positional importance in food webs. Oikos, 112(3), 535-546.

Ferraro, P. J., McIntosh, C., \& Ospin, M. (2007). The effectiveness of the US endangered species act: An econometric analysis using matching methods. Journal of Environmental Economics and Management, 54(3), 245-261.

Foin, T. C., Riley, S. P., Pawley, A. L., Ayres, D. R., \& Carlsen, T. M. (1998). Improving recovery planning for threatened and endangered species. BioScience, 48(3), 177-184.

Fortin, M., Drapeau, P., \& Legendre, P. (1989). Spatial autocorrelation and sampling design in plant ecology. Vegetatio, 83, 209-222.

Franklin, J. (1995). Predictive vegetation mapping: geographical modeling of biospatial patterns in relation to environmental gradients. Progress in Physical Geography, 19(4), 474-499.

Gerber, L. R., \& Hatch, L. T. (2002). Are we recovering? An evaluation of recovery 
criteria under the U.S. Endangered Species Act, Ecological Applications, 12(3), 668-673.

Gerber, L. R., \& Schultz, C. (2001). Authorship and the use of biological information in endangered species recovery plans. Conservation Biology, 15(5), 1308-1314.

Gordon, R. E., Lacy, J. K., \& Streeter, J. R. (1997). Conservation under the endangered species act. Environment International, 23(3), 359-419.

Guisan, A., Lehmann, A., Ferrier, S., Austin, M., Overton, M. C. C., Aspinall, R., \& Hastie, T. (2006). Making better biogeographical predictions of species distributions. Journal of Applied Ecology, 43, 386-392.

Guisan, A., Theurillat, J. P., \& Kienast, F. (1998). Predicting the potential distribution of plant species in an alpine environment. Journal of Vegetation Science, 9(1), 65-74.

Gurevitch, J., \& Hedges, L. J. (1999). Statistical issues in ecological meta-analyses. Ecological Society of America, 80(4), 1142-1149.

Gustafsson, C., \& Bostrom, C. (2011). Biodiversity influences ecosytem functioning in aquatic angiosperm communities Oikos, 120(7), 1037-1046.

Haines, A. M., Zak, M., Hammond, K., Scott, J. M., Goble, D. D., \& Rachlow, J. L. (2013). Uncertainty in population estimates for endangered animals and improving the recovery process. Animals, 3, 745-753.

Hatcher, D., Eaton, J., Gibson, M., \& Leah, R. (1999). Methodologies for surveying plant communities in artificial channels. Hydrobiologia, 415, 87-91.

Heinken, T., \& Weber, E. (2013). Consequences of habitat fragmentation for plant species: Do we know enough? Perspectives in Plant Ecology, Evolution and Systematics, 15(4), 205-216.

Henle, K., Davies, K. F., Kleyer, M., Margules, C., \& Settele, J. (2004). Predictors of species sensitivity to fragmentation. Biodiversity and conservation, 13, 207251.

Heppell, S. S., Caswell, H., \& Crowder, L. B. (2000). Life histories and elasticity patterns: Perturbation analysis for species with minimal demographic data. Ecology, 81(3), 654-665.

Holmes, E. E. (2001). Estimating risks in declining populations with poor data. Proceedings of the National Academy of Science, 98(9), 5072-5077.

IUCN. (2010). Guidelines for using the IUCN Red List categories and criteria. Version 


\section{1: Standards and Petitions Subcommittee.}

Jacqmain, H., Bélanger, L., Courtois, R., Dussault, C., Beckley, T. M., Pelletier, M., \& Gull, S. W. (2012). Aboriginal forestry: development of a socioecologically relevant moose habitat management process using local Cree and scientific knowledge in Eeyou Istchee. Canadian Journal of Forest Research, 42(4).

Janzen, D. H., \& Hallwachs, W. (2011). Joining inventory by parataxonomists with DNA barcoding of a large complex tropical conserved wildland in northwestern Costa Rica. PLoSONE, 6(8).

Jones, C. C., Acker, S. A., \& Halpern, C. B. (2010). Combining local- and large-scale models to predict the distributions of invasive plant species. Ecological Applications, 20, 311-326.

Karst, A. (2010). Conservation Value of the North American Boreal Forest from an Ethnobotanical Perspective. . Canadian Boreal Initiative, David Suzuki Foundation and Boreal Songbird Initiative; Ottawa, ON; Vancouver, BC; Seattle, WA. .

Kokko, H., \& Ebenhard, T. (1996). Measuring the strength of demographic stochasticity. Journal of Theoretical Biology, 183(2), 169-178.

Lande, R. (1994). Risk of population extinction from fixation of new deleterious mutations. Evolution, 1460-1469.

Laws, J. (2002). S.C. 2002, c. 29 (Species at Risk Act). Canada: http://lawslois.justice.gc.ca/eng/acts/s-15.3/FullText.html.

Leidner, A. K., \& Neel, M. C. (2011). Taxonomic and geographic patterns of decline for threatened and endangered species in the united states. Conservation Biology, 25(4), 716-725.

Lienert, J. (2004). Habitat fragmentation effects on fitness of plant populations - a review. Journal for Nature Conservation, 12(1), 53-72.

Lodge, D. M., Williams, S., MacIsaac, H. J., Hayes, K. R., Leung, B., Reichard, S., . . . McMichael, A. (2006). Biological Invasions: Recommendations for US policy and management. Ecological Applications, 16(6), 2035-2054.

MacArthur, R. H., \& Wilson, E. O. (1967). The Theory of Island Biogeography. Princeton, N.J: Princeton University Press.

Mace, G. M., Collar, N., Cooke, J., Gaston, K. J., Ginsberg, J. R., Leader-Williams, N., . . Milner-Gulland, E. J. (1992). The development of new criteria for listing species on the IUCN Red List. Species, 19, 16-22. 
Mace, G. M., \& Lande, R. (1991). Assessing extinction threats: toward a re-evaluation of IUCN threatened species categories. Conservation Biology, 5(2), 148-157.

MacKenzie, D. I., Nichols, J. D., Sutton, N., Kawanishi, K., \& Bailey, L. L. (2005). Improving inferences in population studies of rare species that are detected imperfectly. Ecology, 86(5), 1101-1113.

Male, T. D., Walsh, S., \& Bean, M. J. (2006). A recovery index: developing a new metric to track endangered species recovery progress. Endangered Species UPDATE, 23(2).

Mandelik, Y., Roll, U., \& Fleischer, A. (2010). Cost-efficiency of biodiversity indicators for Mediterranean ecosystems and the effects of socio-economic factors. Journal of Applied Ecology, 47, 1179-1188.

Marba, N., Duarte, C. M., \& Agusti, S. (2007). Allometric scaling of plant life history. PNAS, 104(40), 15777-15780.

Melville, G. J., \& Welsh, A. H. (2001). Line transect sampling in small regions. Biometrics, 57(1130-1137).

Miller, B., Reading, R., Conway, C., Jackson, J. A., Hutchins, M., Snyder, N., \& Frazier, J. (1994). A model for improving endangered species recovery programs. Environmental Management, 18(5), 637-645.

Miller, J. K., Scott, M., Miller, C. R., \& Waits, L. P. (2002). The endangered species act: dollars and sense? . BioScience, 52(2), 163-168.

Mooers, A. O., Prugh, L. R., Festa-Bianchet, M., \& Hutchings, J. A. (2007). Biases in legal listing under Canadian Endangered Species Legislation. Conservation Biology, 21(3), 572-575.

Morisita, M. (1959). Measuring of the dispersion of individuals and analysis of the distributional patterns. Mem. Fac. Sci. Kyushu Univ. Ser. E, 2(21), 5-235.

National Council for Air and Stream Improvement, I. N. (2004). Managing elements of biodiversity in sustainable forestry programs: Status and utility of NatureServe's information resources to forest managers. National Council for Air and Stream Improvement Technical Bulletin No 885.

Neel, M. C., \& Che-Castaldo, J. (2013). Predicting recovery criteria for threatened and endangered plant species on the basis of past abundances and biological traits. Conservation Biology, 27(2), 385-397.

Neel, M. C., Leidner, A. K., Haines, A., Goble, D. D., \& Scott, M. J. (2012). By the 
numbers: How is recovery defined by the US endangered species act? BioScience, 62(7), 646-657.

Nock, C. J., Waters, D. L., Edwards, M. A., Bowen, S. G., Rice, N., Cordeiro, G. M., \& Henry, R. J. (2011). Chloroplast genome sequences from total DNA for plant identification. Plant biotechnology journal, 9(3), 328-333.

Norton, B. R. (1988). Avoiding the triage questron. Endangered Species Update, 5(8), $1-4$.

Ontario Endangered Species Act. 2007. Bill 184: an act to protect species at risk and to make related changes to other acts. Available from http://www.ontla.on.ca/bills/billsfiles/38_Parliament/Session2/b184.pdf (accessed December 2008)

Pang, X., Song, J., Zhu, Y., Xu, H., Huang, L., \& Chen, S. (2011). Applying plant DNA barcodes for Rosaceae species identification. Cladistics, 27(2), 165-170.

Possingham, H. P., Andelman, S. J., Burgman, M. A., Medellín, R. A., Master, L. L., \& Keith, D. A. (2002). Limits To The Use Of Threatened Species Lists. Trends in Ecology \& Evolution, 17(11), 503-507.

Potts, J. M., \& Elith, J. (2006). Comparing species abundance models. Ecological modelling, 199, 153-163.

Rabinowitz, D. (1981). Seven forms of rarity, In The biological aspects of rare plant conservation. Chichester, UK:: John Wiley \& Sons.

Rabinowitz, D., Cairns, S., \& Dillon, T. (1986). Seven forms of rarity and their frequency in the flora of the British Isles. In Conservation biology: The science of scarcity and diversity, . Sunderland, MA: Sinauer Associates.

Regan, T. J., McCarthy, M. A., Baxter, P. W. J., Panetta, F. D., \& Possingham, H. P. (2006). Optimal eradicationL when to stop looking for an invasive plant. Ecology Letters, 9, 759-766.

Rew, L. J., Maxwell, B. D., \& Aspinall, R. (2005). Predicting the occurrence of nonindigenous species using environmental and remotely sensed data. Weed Science Society of America, 53(2), 236-241.

Rew, L. J., Maxwell, B. D., Dougher, F. L., \& Aspinall, R. (2006). Searching for a needle in a haystack: evaluating survey methods for non-indigenous species. Biological Invasions, 8, 523-539.

Richter-Dyn, N., \& Goel, N. S. (1972). On the extinction of a colonizing species. Theoretical Population Biology, 3(4), 406-433. 
Ringvall, A., Snall, T., Ekstrom, M., \& Goran, S. (2007). Unrestricted guided transect sampling for surveying sparse species. Canadian Journal of Forest Research, $37,2575-2586$.

Robbins, K. (2012). Strength in Numbers: Setting Quantitative Criteria for Listing Species Under the Endangered Species Act. UCLA Journal of Environmental Law \& Policy, 27(1).

Roesch, F. A. J. (1993). Adaptive cluster sampling for forest inventories. Forest Science, $39,655-669$.

Rohlf, A. J. (1991). Six biological reasons why the endangered species act doesn't work and what to do about it. Conservation Biology, 5(3), 273-282.

Schemske, D. W., Husband, B. C., Ruckelshaus, M. H., Goodwillie, C., Parker, I. M., \& Bishop, J. G. (1994). Evaluating approaches to the conservation of rare and endangered plants. Ecology, 75(3), 584-606.

Shultz, C. B., \& Gerber, L. R. (2002). Are recovery plans improving with practice? Ecological Applications, 12(3), 641-647.

Sleep, D. J. H., \& Trout, L. (2013). A review of the history and scientific basis of species at risk assessments in Canada. National Council for Air and Stream Improvement, Technical Bulletin No. 1005.

Stohlgren, T. J., Quinn, J. F., Ruggiero, M., \& Waggoner, G. S. (1994). Status of biotic inventories in US National Parks. Biological Conservation, 71, 97-106.

Taylor, M. F. J., F., S. K., \& Rachlinski, J. J. (2005). The effectiveness of the endangered species act: a quantitative analysis. Bioscience, 55(4), 360-367.

Tear, T. H., Scott, J. M., Hayward, P. H., \& Griffith, B. (1995). Recovery plans and the endangered species act: are criticisms supported by data? Conservation Biology, 9(1), 182-195.

Thompson, S. K. (1992). Adaptive cluster sampling. American Statistical Association, $85,1050-1059$.

Thompson, W. L. (2004). Sampling rare or elusive species: concepts, designs, and techniques for estimating population parameters: Island Press.

USDA, NRCS. 2014. The PLANTS Database (http://plants.usda.gov, 7 May 2014). National Plant Data Team, Greensboro, NC 27401-4901 USA.

Venter, O., Brodeur, N. N., Nemiroff, L., Belland, B., Dolinsek, I. J., \& Grant, J. W. A. 
(2006). Threats to Endangered Species in Canada BioScience, 56(11), 904910.

Verloove, F. (2010). Invaders in disguise: conservation risks derived from misidentifications of invasive plants Management of Biological Invasions, 1 , $1-5$.

Vindenes, Y., Engen, S., \& Saether, B. E. (2008). Individual heterogeneity in vital parameters and demographic stochasticity. The American Naturalist, 171(4), 455-467. 